\title{
Corrosion Inhibition of Carob Pod Pulp (Ceratonia siliqua L.) on Carbon Steel Surface C38 in Hydrochloric Acid
}

\author{
I. Ghazi ${ }^{1,2}$ (1) M. Zefzoufi ${ }^{3} \cdot$ M. Siniti ${ }^{1} \cdot$ R. Fdil ${ }^{3} \cdot$ H. Elattari ${ }^{2}$
}

Received: 10 November 2021 / Revised: 24 December 2021 / Accepted: 4 January 2022 / Published online: 13 January 2022

(C) The Author(s), under exclusive licence to Springer Nature Switzerland AG 2022

\begin{abstract}
The effect of $C$. siliqua pulp corrosion inhibition on carbon steel has been studied by gravimetric testing and electrochemical methods. In this study, two raw extracts were prepared from the pod pulp of $C$. siliqua: the first is methanolic and the second is aqueous. The UHPLC/DAD analysis indicated gallic acid's presence in the extracts (methanolic and aqueous) of C. siliqua as a major compound. The inhibition results achieved revealed that the aqueous extract with gallic acid had a good anticorrosion activity with an inhibition rate of $91.32 \%$ at $3 \mathrm{~g} / \mathrm{l}$ for a temperature of $323 \mathrm{~K}$. Potentiodynamic polarization was performed in $1 \mathrm{M} \mathrm{HCl}$ without and with different concentrations of $C$. siliqua extracts clearly proves that inhibitor extracts behave as mixed type. Adsorption of this inhibitor for different extracts studied on the surface of the carbon steel obeys Langmuir adsorption with negative values of $\Delta G_{\mathrm{ads}}^{\circ}$, suggesting a stable and spontaneous inhibition process.
\end{abstract}

Keywords Carbon steel $\cdot$ Corrosion $\cdot$ Gravimetric $\cdot$ Inhibition $\cdot$ Ceratonia siliqua

\section{Introduction}

The study of carbon steel corrosion in $\mathrm{HCl}$ acid solution has grown relevant, owing to the numerous industrial applications of acid solutions, particularly in pickling, rescaling, and cleaning of steel surfaces [1]. Therefore, steels and its alloys dissolve considerably when exposed to acid solutions or aggressive environments. Therefore, these acids cause the degradation of metals, which leads to the problem of corrosion, which is a very common problem, difficult to eliminate completely. Steel dissolution and consumption are controlled using inhibitors. In general, inhibitors are organic molecules that contain oxygen, sulfur, and nitrogen atoms [2-10]. The

I. Ghazi and M. Zefzoufi have contributed equally to this work.

I. Ghazi

inass0100@hotmail.fr

1 Research Team "Thermodynamic Catalysis and Surfaces", Department of Chemistry, Faculty of Science, University of Chouaib Doukkali, BP: 20, 24000 El Jadida, Morocco

2 Laboratory of Coordination and Analytical Chemistry, Department of Chemistry, Faculty of Science, University of Chouaib Doukkali, BP: 20, 24000 El Jadida, Morocco

3 Laboratory of Bioorganic Chemistry, Department of Chemistry, Faculty of Science, University of Chouaib Doukkali, BP: 20, 24000 El Jadida, Morocco presence of attractive interactions between the corroding surface of metal and the adsorbate is required for adsorption. Adsorption can be classified as physisorption, chemisorption, or a mixture of both depending on the type of forces involved [11-14]. Functional groups, steric factor, and aromaticity are all factors that influence the adsorption behavior of organic molecules [15]. A large number of organic synthetic inhibitors are highly toxic and, therefore, have negative consequences on humans and the environment [16] and can cause temporary or permanent damage to organ systems such as kidneys or liver, or disrupt the enzyme system in the body [17]. Nowadays, research interests are directed towards the application of green inhibitors (i.e., environmentally friendly compounds). Therefore, the inhibitor used must be cost effective and also readily available. Furthermore, due to recent environmental awareness and restrictions, the inhibitor must be non-toxic and biodegradable [18]. As a result, plant extracts are increasingly being considered as a source of corrosion inhibitors. They are used for metal protection in acidic environments to replace the toxic chemicals currently used [19]. The inhibitory performance of plant extracts is generally linked to the presence in these extracts of primary metabolites such as sugars, proteins, or lipids but above all, to the presence of secondary metabolites such as alkaloids, polyphenols, and terpenoids. These metabolites contain polar functions with oxygen, sulfur, nitrogen atoms 
and double- or triple-conjugated bonds with aromatic rings, which are the principal adsorption centers in their chemical structures [20, 21].

Several studies have been published on the use of various plant parts such as leaves [22], fruits [23], seeds [24], and flowers [25]. They have been extracted by simple lowcost procedures and studied as corrosion inhibitors in different media; for example, Prabha et al. [26] have studied the corrosion inhibition of mild steel by aqueous extract of Andrographis paniculata. A leguminous plant of Retama monosperma was used as a corrosion inhibitor of carbon steel in $1 \mathrm{M} \mathrm{HCl}$ solution by El Hamdani et al. [27]. Kathiravan et al. [28] studied the inhibitory action of aqueous extract of Ruellia tuberosa leaves on copper corrosion in $0.5 \mathrm{M} \mathrm{HCl}$. Carob (C. siliqua) is a tree that has been popular in the Mediterranean region. It is a member of the Legume family (Fabaceae) [29]. After the seeds have been removed from the fruit pod, carob powder is obtained [30]. The pulp (90\%) and seeds (10\%) are the main components of carob pod by weight [31]. In fact, the pulp of carob has been used for centuries in human nutrition, i.e., to prepare cakes, bread and flakes [32,33], chocolate, cookies and as a substitute for cocoa, cereal bars, ice creams [34, 35], as well as in animal feed (horses, ruminants) [36] alongside other feeds such as barley flour [37]. The pods, after removal of their seeds, are used mainly in the food industry [38] as an antioxidant due to their rich polyphenols composition. Numerous clinical studies have highlighted the effectiveness of carob powder in the treatment of acute childhood diarrhea [39]. According to Rejeb [40], the pulp is recommended against pulmonary tuberculosis and bronchial affections. This plant is known in therapeutics for its hypocholesterolemic effect, antiproliferative, antidiarrheal, and digestive disorders [41]. The high fiber content of carob suggests that it could reduce blood cholesterol levels [42]. The carob pods have a high concentration of condensed tannins (16-20\%), which are composed of flavan-3-ol groups and their galloyl esters [43, 44], gallic acid $[45,46],(+)$-catechin, (-)-epicatechingallate, (-)-epigallocatechingallate, and quercetin glycosides [47].

As for gallic acid, 3,4,5-trihydroxy benzoic acid is a triphenolic acid, colorless, or slightly yellow, is widely present in the plant kingdom as a secondary metabolite and widely present in free form or as a derivative in various food sources such as nuts, tea, grapes, and sumac (Rhus coriaria L.) [48-50]. Other sources include gallnuts, oak bark, honey, various berries, pomegranate, mango and other red fruits, beverages [51-54], and vegetables especially in black radish and onions [55]. Gallic acid is found in plant tissues as an ester and various esters with sugar glycosides, polyols and phenols [56]. It is a proposed reductant in dilute chemical decontamination formulations due to its inherent stability against radiation degradation [57]. Gallic acid significantly slows down-scale formation and, thus, has been shown to be an effective scale inhibitor at very low concentrations [58]. It has a wide range of applications in the health, food, and pharmaceutical industries, in the manufacture of inks, paints, dyes, and also in cinematography [59]. In fact, it seems to have an antiasthmatic effect [60] and inhibits the formation of esophageal cancer in rats [61]. It has a cytotoxic activity against cancer cells (leukemia, prostate cancer, lung cancer) [62]. Kratz et al. [63] showed that gallic acid had anti-viral activity against the herpes virus HSV-2. Further, Umar et al. [64] revealed that gallic acid is used as a therapeutic compound and an inhibitor against five key non-structural proteins in the recent coronavirus epidemic caused by the novel coronavirus SARS-CoV-2. In addition, gallic acid has been shown to be a protective antioxidant for plants against environmental aggression (temperature, light) or pathogens. It is used in routine tests as a reference substance in antioxidant activities [65] and also shows a higher antiradical activity than ascorbic acid or oxalic acid [66].

It is more recommended that gallic acid itself can also be useful as a corrosion inhibitor in the decontamination process; this can avoid the addition of another component in the formulation as a corrosion inhibitor [67]. Gallic acid is used as a non-toxic corrosion inhibitor for steel structures instead of toxic lead oxide (or red oxide). The possibility of covering the steel surface with an insoluble gallic acid-iron complex can be one of the reasons for corrosion inhibition [68]. In gold electroless plating studies with a 1,2-hydroquinone fraction, gallic acid due to its high reduction potential, was found to adsorb onto the metal surface and function as a corrosion inhibitor [69]. Obot et al. [70] studied the corrosion-inhibiting effect of tannic acid in the presence of gallic acid at the mild steel/ $\mathrm{HCl}$ acid solution interface; indeed, the inhibition effect of tannic acid is enhanced by its combination with gallic acid. As well as a suitable inhibitory characteristic of gallic acid was found to be equally effective in the inhibition properties of henna extract by Ostovari et al. [17].

The objective of this research was to investigate the effects of inhibition of $C$. siliqua pulp of extracts (aqueous and methanolic) both without and with gallic acid on carbon steel corrosion $\mathrm{C} 38$ in $1 \mathrm{M} \mathrm{HCl}$. The performance of inhibition is analyzed by weight loss, potentiodynamic polarization, as well as impedance spectroscopy. The inhibitor's adsorption isotherm on carbon steel was determined.

\section{Materials and Methods}

\subsection{Preparation of Specimens and Solutions}

Throughout the experiments, carbon steel was employed. The specimens of carbon steel used in this study are rectangular in shape $\left(4 \times 1 \mathrm{~cm}^{2}\right)$ and contain the following composition: 
$(\mathrm{C}=0.38 \%, \mathrm{Mn}=0.68 \%, \mathrm{Si}=0.23 \%, \mathrm{~S}=0.02 \%, \mathrm{P}=0.001 \%)$ and the remainder of iron. Analytical Grade $37 \% \mathrm{HCl}$ was diluted with distilled water to prepare the aggressive $\mathrm{HCl}$ acid solution $1 \mathrm{M}$. All of the studies were done in $1 \mathrm{M} \mathrm{HCl}$ solution in the absence and presence of various inhibitor concentrations $(0.5 ; 1 ; 1.5 ; 2 ; 2.5$; and $3 \mathrm{~g} / \mathrm{l})$.

\subsection{Preparation of Plant Extracts}

The dried carob pods of $C$. siliqua were collected in July 2017 in the northwest of Morocco (Gharb-Chrarda ouezzane). The samples were deposited in the Bioorganic Chemistry Laboratory at Chouaib Doukkali University in El Jadida. In the laboratory, the pulp was separated from the seed of the pods; the different parts of $C$. siliqua pulp were crushed in a fine powder mortar.

\subsubsection{Methanol and Water Extracts}

The vegetable material to be extracted was weighed (60 g) and placed in the Cartridge of Soxhlet. The distilled methanol $(250 \mathrm{ml})$ was introduced to the flask, which was then heated to begin the extraction process until the plant was totally exhausted. A $46 \mathrm{~h}$ time was spent extracting the plant with methanol.

For the preparation of the aqueous extract, the same quantity of crushed pulp ( $60 \mathrm{~g}$ ) was extracted until exhaustion, for a period of $28 \mathrm{~h}$ by following the same extraction technique (Soxhlet).

The resulting liquid extracts were then concentrated using a rotary evaporator to give $29.42 \mathrm{~g}$ and $30.14 \mathrm{~g}$ of methanolic and aqueous extracts, respectively. These two extracts of the plant were used to prepare the concentrations mentioned above. Figure 1 depicts the chemical structures of some active components found in $C$. siliqua extracts (methanolic and aqueous).

\subsection{UHPLC/DAD analysis}

The studied extracts were subjected to UHPLC-DAD analysis. The phenolic compounds were identified as previously explained by Puigventos et al. [72] Liquid chromatography system (Dionex Ultimate 3000, CA, USA), equipped with an autosampler (WPS 3000 TSL), a quaternary pump (HPG $3400 \mathrm{RS}$ ), and a column oven (TCC 3000). A Kinetex C18 reversed phase column

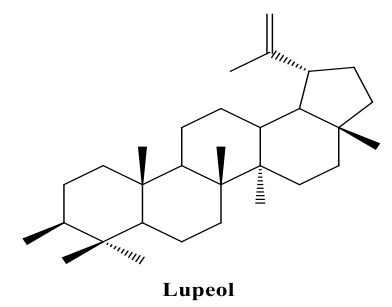<smiles>O=c1c(-c2ccc(O)cc2)coc2cc(O)cc(O)c12</smiles><smiles>O=C1C=C(c2ccc(O)cc2)Cc2cc(O)ccc21</smiles>

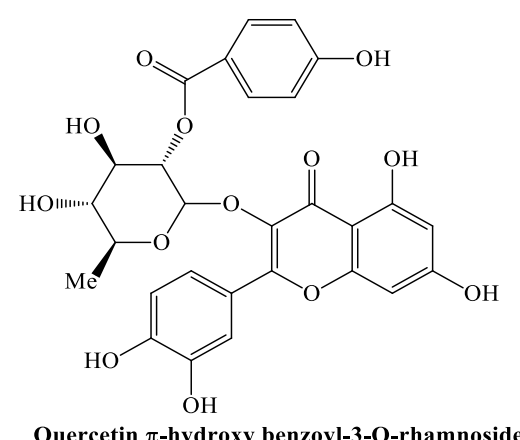<smiles>COc1cc(C2=CC(=O)c3ccc(O)cc3C2)ccc1O</smiles><smiles>[Y4][C@H]1OC(Oc2c(-c3ccc(OC(=O)c4ccc(O)cc4)c(OC)c3)oc3cc(O)cc(O)c3c2=O)[C@H](O)[C@@H](O)[C@H]1O</smiles><smiles>O=C(O)c1cc(O)c(O)c(O)c1</smiles>

Gallic acid (3,4,5-trihydroxybenzoic acid)

Fig. 1 Some secondary metabolites separated from C. siliqua extracts [71] 
$(250 \times 4.6 \mathrm{~mm}, 2.6 \mu \mathrm{m}$ particles $)$ provided by Thermo Fisher Scientific (CA, USA) was used for the proposed method. The solvent was used to create a gradient separation A ( $0.1 \%$ formic acid aqueous solution) and solvent B (methanol) as follows: 0-3 min, linear gradient from 5 to $25 \% \mathrm{~B} ; 3-6 \mathrm{~min}$, at $25 \% \mathrm{~B} ; 6-9 \mathrm{~min}$, from 25 to $37 \% \mathrm{~B} ; 9-13 \mathrm{~min}$, at $37 \% \mathrm{~B} ; 13-18 \mathrm{~min}$, from 37 to $54 \%$ $\mathrm{B} ; 18-22 \mathrm{~min}$, at $54 \% \mathrm{~B} ; 22-26 \mathrm{~min}$, from 54 to $95 \% \mathrm{~B}$; 26-29 min, at $95 \% \mathrm{~B} ; 29-29.15 \mathrm{~min}$, back to initial conditions at $5 \% \mathrm{~B}$; and from 29.15 to $36 \mathrm{~min}$, at $5 \% \mathrm{~B}$. The mobile phase flow rate was $1 \mathrm{ml} / \mathrm{min}$. The DAD detector Dionex Ultimate 3000 was detected at $280 \mathrm{~nm}$. Retention times and UV spectra were compared to standards to identify the compounds investigated in the extracts (aqueous and methanolic). All eleven standards used for analyses were obtained from Sigma-Aldrich (Berin, Germany): stock solution: gallic acid, catechine, Chlorogenic acid, Epicathechine, vanillin, $\pi$-Coumaric acid, Sinapic acid, naringine, Rutin, quercetin, and kaempferol. Three series and repetition of stock solution standars at 5 concentration levels were used $(10,50,100,150$ and $200 \mathrm{mg} / \mathrm{l})$ for this quantitative analysis.

\subsection{Gravimetric Method}

The specimens were abraded using an emery papers collection (grades $360 ; 400 ; 600 ; 1200 ; 1500 ; 2000$ ), then carefully cleaned with acetone and distilled water and dried. At a constant temperature regulated by a water thermostat, the specimens were immersed in $(30 \mathrm{ml})$ vials containing acid $1 \mathrm{M} \mathrm{HCl}$ without and with varying concentrations of the inhibitor being studied. The specimens were abducted after $6 \mathrm{~h}$, rinsed, dried, and precisely weighed. The experiments were then carried out at various temperatures. Equation (1) is used to compute the weight loss $\Delta_{m}(\mathrm{mg})$ :

$\Delta_{m}=m_{1}-m_{2}$

where $m_{1}$ is the starting weight before immersion and $m_{2}$ is the final weight after immersion.

Equation (2) is used to get the corrosion rate $(w)$ :

$w\left(\mathrm{mg} / \mathrm{cm}^{2} \mathrm{~h}^{-1}\right)=\Delta_{m} / \mathrm{s.t}$

$S$ is the geometrical surface area $\left(\mathrm{Cm}^{2}\right)$, and $t$ is the corrosion test period (h).

The inhibitory efficiency $E(\%)$ was estimated using the following formula (3):

$E(\%)=\left[\left(w_{0}-w_{\text {inh }}\right) / w_{0}\right] \times 100$,

where $w_{0}$ and $w_{\text {inh }}$ are, respectively, the corrosion rates without and with $C$. siliqua inhibitor.

\subsection{Electrochemical Method}

The samples of steel $1 \mathrm{~cm}^{2}$ are prepared as described above (Section gravimetric determination) and were first immersed into the solution for $30 \mathrm{~min}$ to establish a steady-state open-circuit potential. Platinum electrode and a saturated calomel (SCE) electrode were used as auxiliary and reference electrodes, respectively. The material used is potentiostat/galvanostat/FRA, SP 200 EC-Lab Research Grad type. EC-Lab software was used to examine the data. The effect of inhibitor on steel corrosion was determined by measuring corrosion rate in different concentrations of the pulp of $C$. siliqua. For the evaluation of inhibitor concentration effects on inhibition efficiency (the protection of corrosion), experiments were carried out in the presence and absence of $\mathrm{HCl} 1 \mathrm{M}$ of various concentrations of inhibitor. At normal temperature $\left(25^{\circ} \mathrm{C}\right)$, the cell was left exposed to the air. Curves of potentiodynamic polarization in the potential range between $\pm 10(\mathrm{~V})$ relative to the $E_{\text {ocp }}$ were obtained after measuring the potential in an open circuit at a scan rate of $1\left(\mathrm{mV} \mathrm{s}^{-1}\right)$. Values of corrosion current densities were obtained by extrapolating the tafel lines (anodic and cathodic). The efficiency of inhibition $E(\%)$ is defined as follows:

$E(\%)=\left[1-\left(i_{\text {corr }}^{0} / i_{\text {corr }}^{\text {inh }}\right)\right] \times 100$,

where $\mathrm{i}_{\mathrm{Corr}}^{0}$ and $\mathrm{i}_{\mathrm{Corr}}^{\mathrm{inh}}$ reflect values for current densities of corrosion without and with inhibitor, respectively. Spectroscopy of electrochemical impedance technical (EIS) was carried out in the presence of open-circuit potential at the frequency ranges between $100(\mathrm{kHz})$ and $10(\mathrm{mHz})$, with a $10 \mathrm{mV}$ change in signal amplitude. The following equation is used to calculate inhibition efficiency $\mathrm{E}(\%)$.

$E(\%)=\left[\left(R_{\mathrm{ct}}^{\mathrm{inh}}-R_{\mathrm{ct}}^{0}\right) / R_{\mathrm{ct}}^{\mathrm{inh}}\right] \times 100$,

where $\mathrm{R}_{\mathrm{ct}}^{\mathrm{inh}}$ and $\mathrm{R}_{\mathrm{Ct}}^{0}$ are resistance to charge transfer in the presence and absence of the inhibitor, respectively.

\subsection{Fourier Transform Infrared Spectroscopic (FTIR) Analysis}

Fourier transform infrared spectroscopy (FTIR) was studied in the frequency range $400-4000 \mathrm{Cm}^{-1}$ for the solution of $1 \mathrm{M} \mathrm{HCl}+3 \mathrm{~g} / \mathrm{l}$ of $C$. siliqua and specimen before and after the corrosion test by using a SHIMADZU FTIR 8400S spectrometer with a Smart iTR Attachment and diamond attenuated Total Reflectance (ATR) crystal. The immersed was for $24 \mathrm{~h}$ in $298 \mathrm{~K}$. The experimental data are analyzed by OMNIC software. 


\subsection{X-ray Diffraction Analysis}

X-ray diffraction (XRD) analysis was performed with a BRUKER X D8 ADVANCE-ECO. Metal specimens prepared were immersed in solutions for a period of $6 \mathrm{~h}$ at $303 \mathrm{~K}$, and the patterns of the phases/films on the prepared steel surface before and after immersion in $1 \mathrm{M} \mathrm{HCl}$, without and with $3 \mathrm{~g} / \mathrm{l}$ of $C$. siliqua aqueous extract in the absence and presence of gallic acid were identified using PANalytical HighScore plus. The XRD patterns were recorded in the angular range of $2 \theta$ from $10^{\circ}$ to $70^{\circ}$ with step size $0.06^{\circ}$ and scan step time $1.0(\mathrm{~s})$.

\subsection{Scanning Electron Microscope (SEM) and Energy Dispersive X-ray Spectroscopy (EDS) analysis}

The metal specimens prepared were immersed for a period of $6 \mathrm{~h}$ in $1 \mathrm{M} \mathrm{HCl}$ without and with $3 \mathrm{~g} / \mathrm{l}$ of $C$. siliqua aqueous extract at $303 \mathrm{~K}$ in the absence and presence of gallic acid and then were removed carefully and thoroughly washed with distilled water and then dried properly. SEM images were taken using HITACHI S-570 model scanning electron microscope and the compositional alteration of the elemental exposed surface was examined via energy dispersive X-ray spectroscopy (EDS) using X-FLASH 6/10 BRUKER with an accelerating voltage of $20 \mathrm{kV}$.

\section{Results and Discussion}

\subsection{UHPLC/DAD Analysis}

A method coupling chromatography with ultra-high-performance liquids (UHPLC) with diode-array detector (DAD) was optimized for the separation and identification of phenolic compounds in the extracts (aqueous and methanolic) of $C$. siliqua. The results showed that regression curves of each compound phenolic were discovered to be linear with $R^{2}$ greater than 0.99 .

In the present study, the analysis by UHPLC/DAD/ ESI-MS showed some similarity of the chromatographic profiles obtained for methanolic (a) and aqueous (b) extracts. In particular, we can note the predominance in the two extracts of the peak eluted at $6.5 \mathrm{~min}$ (Fig. 2 and Table 1). As can be seen from the three chromatograms (Fig. 2), the major compound in the two studied extracts is gallic acid (peak 1); the content of this phenolic acid in methanol extract and the aqueous extract is 87.71 and $54.61 \mathrm{mg} / \mathrm{g}$ of extract, respectively. When we compared our results with the literature, we found it similar, Fadel et al. [73] reported that the pulps and seeds of $C$. siliqua growing in Morocco are rich on many phenolic compounds such as gallic acid (17.8\% and 5.01\%, respectively). Also, Ydjedd et al. [74] revealed that the $C$. siliqua growing in Algeria contained five phenolic acids among them gallic acid (27.84\%). Recently, Goulas and Georgiou [75] determined the presence of gallic acid in the Carob fruits growing in Cyprus. Peak numbers correspond to those represented in Table 1.

\subsection{Weight Loss Method}

Table 2 describes the corrosion rate obtained using the technique of mass loss at various concentrations of different $C$. siliqua pulp extracts in a solution $\mathrm{HCl}$ for $6 \mathrm{~h}$ at temperatures ranging from 298 to $323 \mathrm{k}$. Table 2 shows that the corrosive attack of acid on the carbon steel at all temperatures studied in the absence of the inhibitor is too high for all the extracts studied, because of the very aggressive nature of the chloride ions.

Table 2 demonstrates that the corrosion rate of the carbon steel in $\mathrm{HCl} 1 \mathrm{M}$, without and with $C$. siliqua extracts obeys the Arrhenius-type reaction, because it increases with increasing the temperature of the solution. A remarkable decrease in the rate of corrosion of the carbon steel was observed with the addition of an increasing quantity of $C$. siliqua extracts, at each of the studied temperatures. The existence of heteroatoms like oxygen and $\pi$-electrons in the heterocyclic ring system in the molecules of $C$. siliqua may account for the good inhibitive performance observed in this study which facilitates the coordination interaction with iron atoms and leads to a high tendency for protonation in acidic medium. Table 3 lists the values for the inhibition efficiency of carbon steel corrosion in $\mathrm{HCl}$. The data obtained in this table show that, for all the extracts studied, the efficiency of inhibition increased as the inhibitor concentration was raised. This suggests that some of the inhibiting molecules in the extracts have been adsorbed to the metal surface at a high concentration, leading to higher coverage and, thus, protecting the surface from further corrosion attacks. These results are in agreement with the studies carried out on the extract from the Petersianthus macrocarpus plant in $1 \mathrm{M} \mathrm{HCl} \mathrm{[76].}$

Moreover, for extracts (methanolic and aqueous), the efficiency decreases when the temperature is increased. This phenomenon can be explained by desorption of the molecules [77], which can be attributed to the breakdown of the physical interactions at high temperature between the adsorbed molecules of the extract and the metal surface. The same results were obtained by the extract of Ceratonia siliqua used in nitric acid as a corrosion inhibitor of copper and brass [78], as well as in the study conducted by Chefira et al. [79] on the extract of Origanum elongatum used as a green corrosion inhibitor of steel in acid medium, the same adsorption behavior was obtained.

The value of the inhibition efficiency reached $90.17 \%$ at $298 \mathrm{~K}$ and $3 \mathrm{~g} / \mathrm{l}$ for the aqueous extract of $C$. siliqua, indicating that the adsorption of molecules is lower in $C$. siliqua 

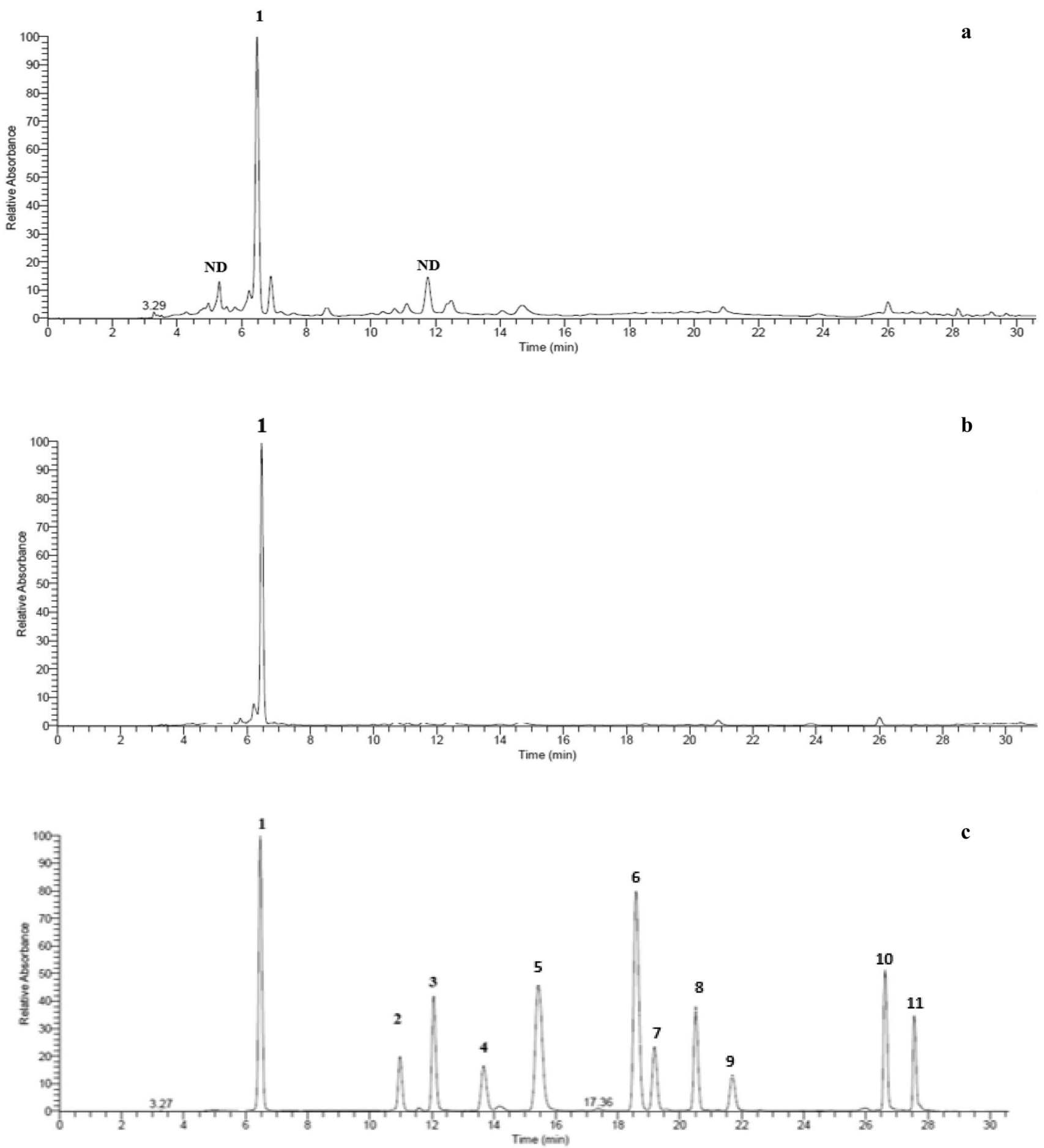

Fig. 2 Chromatographic profiles of methanolic extract (a), aqueous extract of $C$. siliqua (b), and stock solution standards (c) recorded at $280 \mathrm{~nm}$

methanolic extracts than in aqueous extracts. It is clear that from Table 3 in extracts (methanolic and aqueous) with gallic acid, the values of inhibition efficiencies $E(\%)$ increase as the temperature rises (298-323 k). This further confirms the increase in inhibitory effectiveness as concentration of the extract rises. This can be related to the increase in protective inhibitory film formed on the carbon steel surface at higher temperatures. The highest inhibition efficiency was $91.32 \%$ at $323 \mathrm{k}$ and $3 \mathrm{~g} / \mathrm{l}$ for the aqueous extract of $C$. siliqua, indicating that gallic acid can be attributed as the main constituent, responsible for the inhibitory action against corrosion. In effect, gallic acid was also found to be a good corrosion 
Table 1 UHPLCD-DAD analysis of $C$. siliqua extracts and stock solution of standars

\begin{tabular}{|c|c|c|c|c|c|c|c|}
\hline & $R T$ & Standards & $\begin{array}{l}\text { UHPLC-DAD } \\
\lambda_{\max }(\mathrm{nm})\end{array}$ & $\begin{array}{l}\text { Methanolic } \\
\text { mg/g extract }\end{array}$ & $\begin{array}{l}\text { Aqueous } \\
\text { D }\end{array}$ & Linear equation & $R^{2}$ \\
\hline 1 & 6.47 & Gallic acid & 272 & $87.71 \pm 0.04$ & $54.61 \pm 0.08$ & $y=105,407 x-561.69$ & 0.996 \\
\hline 2 & 10.98 & Catechine & 279 & - & - & $y=106,544 x-1557.59$ & 0.995 \\
\hline 3 & 12.06 & Chlorogenic acid & 280,327 & - & - & $y=108,332 x-2296.63$ & 0.995 \\
\hline 4 & 13.68 & Epicathechine & 279 & - & - & $y=106,325 x-1365.1$ & 0.996 \\
\hline 5 & 13.86 & Vannilic acid & 261,300 & - & - & $y=107,592 x-2473.8$ & 0.994 \\
\hline 6 & 18.59 & $\pi$-Coumaric acid & 310 & - & - & $y=109,948 x-3298.4$ & 0.995 \\
\hline 7 & 18.94 & Sinapic acid & 324 & - & - & $y=106,545 x-1557.6$ & 0.995 \\
\hline 8 & 20.51 & Naringine & 284,320 & - & - & $y=106,101 x-1169.4$ & 0.996 \\
\hline 9 & 21.69 & Rutin & 257,356 & - & - & $y=107,183 x-2116.3$ & 0.994 \\
\hline 10 & 26.62 & Quercetin & 255,368 & - & - & $y=114,660 x-4947.7$ & 0.997 \\
\hline 11 & 27.56 & Kaempferol & 266,366 & - & - & $y=106,325 x-1365.1$ & 0.996 \\
\hline
\end{tabular}

Table 2 Carbon steel's corrosion rate obtained by gravimetric in $\mathrm{HCl}$ $1 \mathrm{M}$ without and with various concentrations of $C$. siliqua extract at 298 to $323 \mathrm{k}$ : a-extract of methanol without gallic acid; b-extract of aqueous without gallic acid; c-extract of methanol with gallic acid; d-extract of aqueous with gallic acid

\begin{tabular}{|c|c|c|c|c|}
\hline $\mathrm{C}(\mathrm{g} / \mathrm{l})$ & $298 \mathrm{~K}$ & $303 \mathrm{~K}$ & $313 \mathrm{~K}$ & $323 \mathrm{~K}$ \\
\hline a. Blanc & 0.1354 & 0.2625 & 0.4958 & 1.4145 \\
\hline 0.5 & 0.0437 & 0.1187 & 0.2916 & 0.8791 \\
\hline 1 & 0.0395 & 0.1062 & 0.1979 & 0.8604 \\
\hline 1.5 & 0.0354 & 0.0895 & 0.175 & 0.7604 \\
\hline 2 & 0.0333 & 0.0791 & 0.152 & 0.6895 \\
\hline 2.5 & 0.0291 & 0.0687 & 0.1229 & 0.6812 \\
\hline 3 & 0.025 & 0.05 & 0.1104 & 0.6583 \\
\hline b. Blanc & 0.4608 & 0.5723 & 1.2377 & 1.8259 \\
\hline 0.5 & 0.1421 & 0.2193 & 0.6997 & 0.9889 \\
\hline 1 & 0.1299 & 0.2181 & 0.5576 & 0.8982 \\
\hline 1.5 & 0.1042 & 0.1875 & 0.5282 & 0.7892 \\
\hline 2 & 0.1017 & 0.1679 & 0.4963 & 0.7009 \\
\hline 2.5 & 0.0698 & 0.1519 & 0.4289 & 0.6936 \\
\hline 3 & 0.0453 & 0.1115 & 0.3738 & 0.6434 \\
\hline c. Blanc & 0.2687 & 0.9021 & 1.2479 & 1.6062 \\
\hline 0.5 & 0.1625 & 0.5146 & 0.6208 & 0.6312 \\
\hline 1 & 0.1541 & 0.45 & 0.5604 & 0.6021 \\
\hline 1.5 & 0.1396 & 0.3937 & 0.4708 & 0.5021 \\
\hline 2 & 0.1271 & 0.3479 & 0.3791 & 0.3646 \\
\hline 2.5 & 0.1229 & 0.3083 & 0.3562 & 0.3354 \\
\hline 3 & 0.1208 & 0.2854 & 0.2604 & 0.3021 \\
\hline d. Blanc & 0.2187 & 0.2437 & 0.3979 & 1.4875 \\
\hline 0.5 & 0.1208 & 0.1229 & 0.1916 & 0.5375 \\
\hline 1 & 0.1125 & 0.1146 & 0.1708 & 0.3396 \\
\hline 1.5 & 0.0979 & 0.1021 & 0.1354 & 0.3271 \\
\hline 2 & 0.0812 & 0.0896 & 0.1083 & 0.2958 \\
\hline 2.5 & 0.075 & 0.0771 & 0.1 & 0.2146 \\
\hline 3 & 0.0687 & 0.0708 & 0.0729 & 0.1291 \\
\hline
\end{tabular}

Table 3 Inhibition efficiency of carbon steel in $\mathrm{HCl} 1 \mathrm{M}$ solution after additions of corrosion inhibitor at different temperatures: a-extract of methanol without gallic acid; b-extract of aqueous without gallic acid; c- extract of methanol with gallic acid; d-extract of aqueous with gallic acid

\begin{tabular}{|c|c|c|c|c|}
\hline $\mathrm{C}(\mathrm{g} / \mathrm{l})$ & $298 \mathrm{~K}$ & $303 \mathrm{~K}$ & $313 \mathrm{~K}$ & $323 \mathrm{~K}$ \\
\hline a. Blanc & - & - & - & - \\
\hline 0.5 & 67.72 & 54.78 & 41.18 & 37.85 \\
\hline 1 & 70.82 & 59.54 & 60.08 & 39.17 \\
\hline 1.5 & 73.85 & 65.9 & 64.7 & 46.24 \\
\hline 2 & 75.4 & 69.86 & 69.34 & 51.25 \\
\hline 2.5 & 78.5 & 73.82 & 75.21 & 51.84 \\
\hline 3 & 81.53 & 80.95 & 77.73 & 53.46 \\
\hline b. Blanc & - & - & - & - \\
\hline 0.5 & 69.16 & 61.68 & 43.46 & 45.84 \\
\hline 1 & 71.81 & 61.89 & 54.95 & 50.8 \\
\hline 1.5 & 77.39 & 67.23 & 57.32 & 56.77 \\
\hline 2 & 77.93 & 70.66 & 59.9 & 61.61 \\
\hline 2.5 & 84.85 & 73.45 & 65.35 & 62.01 \\
\hline 3 & 90.17 & 80.51 & 69.8 & 64.76 \\
\hline c. Blanc & - & - & - & - \\
\hline 0.5 & 39.52 & 42.95 & 50.25 & 60.7 \\
\hline 1 & 42.65 & 50.11 & 55.09 & 62.51 \\
\hline 1.5 & 48.04 & 56.36 & 62.27 & 68.74 \\
\hline 2 & 52.69 & 61.43 & 69.62 & 77.3 \\
\hline 2.5 & 54.26 & 65.82 & 71.45 & 79.12 \\
\hline 3 & 55.04 & 68.36 & 79.13 & 81.19 \\
\hline d. Blanc & - & - & - & - \\
\hline 0.5 & 44.76 & 49.57 & 51.85 & 63.86 \\
\hline 1 & 48.56 & 52.97 & 57.07 & 77.17 \\
\hline 1.5 & 55.23 & 58.1 & 65.97 & 78.01 \\
\hline 2 & 62.87 & 63.23 & 72.78 & 80.11 \\
\hline 2.5 & 65.71 & 68.36 & 74.86 & 85.57 \\
\hline 3 & 68.58 & 70.94 & 81.68 & 91.32 \\
\hline
\end{tabular}


inhibitor of aluminum 6061 in alkaline solutions by the study conducted by Ali et al. [80].

\subsection{Electrochemical Polarization Results}

The polarization curves without and with $C$. siliqua extracts at different concentrations in $\mathrm{HCl} 1 \mathrm{M}$ at $303 \mathrm{k}$ are shown in Fig. 3. Based on the results obtained, it can be noted that the addition of $C$. siliqua extracts leads to a decrease in densities of anodic and cathodic currents and displaces the corrosion potential $\left(E_{\text {corr }}\right)$ towards the more negative values (cathodic). The evolution of the $\log \left(i_{\text {corr }}\right)=f\left(E_{\text {corr }}\right)$ curves according to the concentration of $C$. siliqua extracts is substantially identical. The cathodic polarization curves are represented by straight lines indicating that the reaction of hydrogen reduction at the surface is performed by a pure activation mechanism [81]. The values of the electrochemical parameters obtained by the polarization curves without and with different $C$. siliqua extracts are reported in Table 4.

Based on the results obtained from the table above, it can be noted that the corrosion potential $E_{\text {corr }}$ values for all $C$. siliqua extracts change slightly with concentration, indicating that these extracts inhibit cathodic and anodic reactions and, therefore, these $C$. siliqua extracts can be classified as mixed type but preferably as cathodic inhibitor against corrosion of carbon steel $\mathrm{C} 38$ in a solution of $\mathrm{HCl} 1 \mathrm{M}$. The same observations were obtained by the work of El Hamdani et al. [27] that tested the alkaloid extract of Retama monosperma as an inhibitor for the corrosion of carbon steel in $\mathrm{HCl} 1 \mathrm{M}$ solution. In addition, corrosion current densities $\left(i_{\text {corr }}\right)$ decrease when concentration of all extracts increases. This decrease is likely due to adsorption of $C$. siliqua extracts on the metal surface [82]. The study in Table 4 showed that $\beta_{\mathrm{a}}$ values are approximately constant in the presence of different $C$. siliqua extracts while $\beta_{\mathrm{c}}$ values change, this shows that anodic and cathodic reactions are carried out but that the effect on cathodic reactions is greater. These results are completely in accord with the work carried out on the extract of Artemesia herba albamedium used as corrosion inhibitor of stainless steel in solution $1 \mathrm{M} \mathrm{H}_{3} \mathrm{PO}_{4}$ [83]. It is also noted from the results that the inhibitory efficacy $E(\%)$ increases with the increase in the concentration of $C$. siliqua extracts. The highest inhibition value was obtained for the concentration of $3 \mathrm{~g} / \mathrm{l}(90.44 \%)$ and $(91.27 \%)$ for extracts (methanolic and aqueous) with gallic acid, respectively. The values of inhibition efficiencies, calculated from polarization studies, show the same trend as those obtained from weight loss measurements. A comparison of our results
Fig. 3 Polarization curves of steel in $1 \mathrm{M} \mathrm{HCl}$ containing different concentrations of $C$. siliqua extract: a extract of methanol without gallic acid; b extract of aqueous without gallic acid; $\mathbf{c}$ extract of methanol with gallic acid; $\mathbf{d}$ extract of aqueous with gallic acid
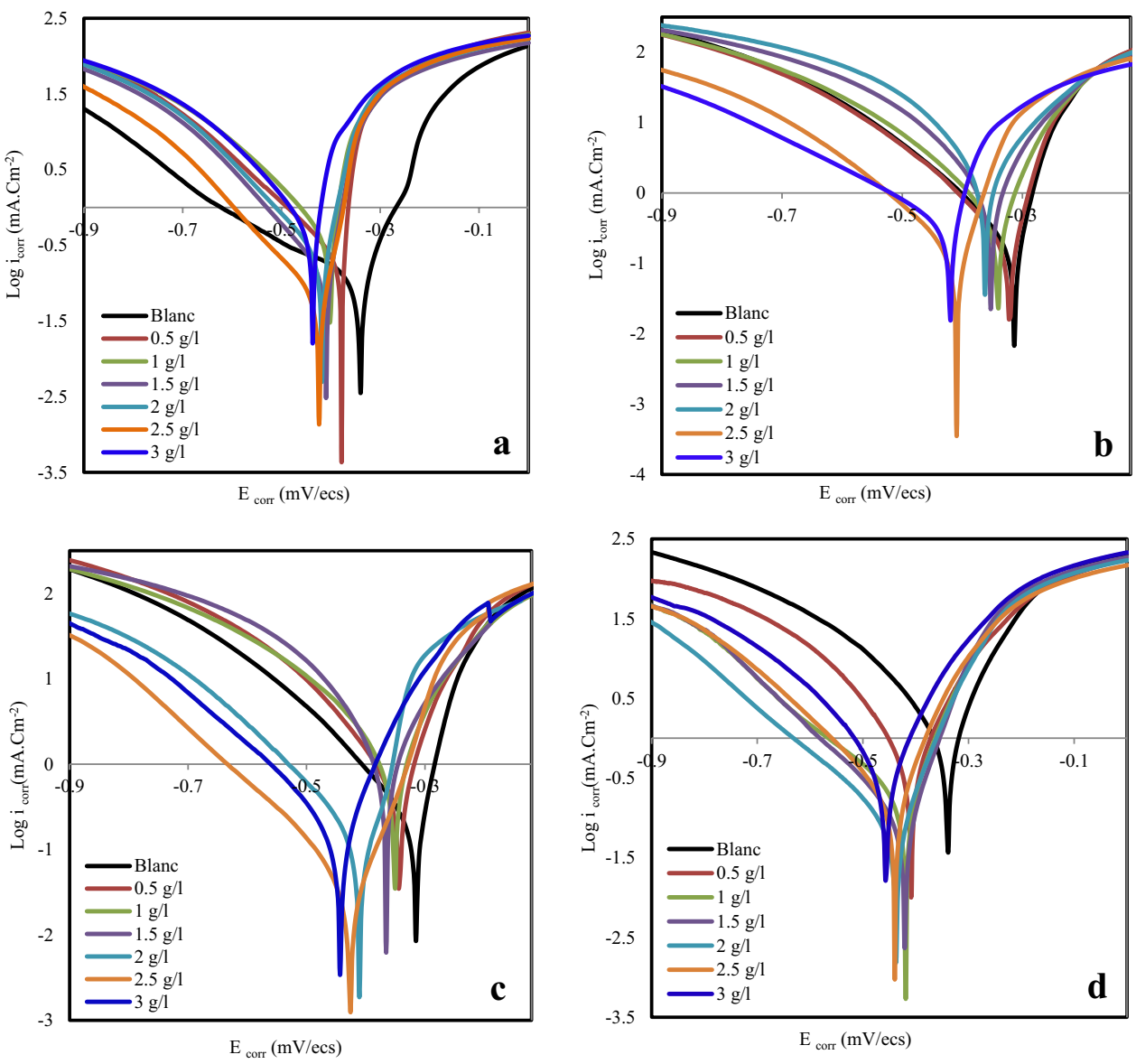
Table 4 Electrochemical parameters for various concentrations of $C$. siliqua extract obtained via polarization curves: a-extract of methanol without gallic acid; b-extract of aqueous without gallic acid; c-extract of methanol with gallic acid; d-extract of aqueous with gallic acid

\begin{tabular}{|c|c|c|c|c|c|}
\hline $\mathrm{C}(\mathrm{g} / \mathrm{l})$ & $\begin{array}{l}E_{\text {corr }}(\mathrm{mv} / \\
\text { ecs })\end{array}$ & $\begin{array}{l}i_{\text {corr }}(\mu \mathrm{A} / \\
\left.\mathrm{cm}^{2}\right)\end{array}$ & $E(\%)$ & $\beta_{\mathrm{a}}(\mathrm{mv} / \mathrm{dec})$ & $\beta_{\mathrm{c}}(\mathrm{mv} / \mathrm{dec})$ \\
\hline a. Blanc & -340.400 & 675.664 & - & 74.0 & 321.3 \\
\hline 0.5 & -378.353 & 317.804 & 52.96 & 23.3 & 176.9 \\
\hline 1 & -402.209 & 294.251 & 56.45 & 48.2 & 166.9 \\
\hline 1.5 & -409.536 & 282.833 & 58.14 & 42.2 & 147.5 \\
\hline 2 & -418.313 & 266.84 & 60.51 & 48.1 & 155.7 \\
\hline 2.5 & -423.765 & 257.903 & 61.83 & 44.9 & 152.1 \\
\hline 3 & -436.624 & 221.374 & 67.23 & 51.8 & 154.5 \\
\hline b. Blanc & -313.208 & 938.576 & - & 75.2 & 217.5 \\
\hline 0.5 & -322.373 & 487.688 & 48.04 & 66.9 & 162.1 \\
\hline 1 & -339.604 & 382.914 & 59.2 & 77.4 & 166.8 \\
\hline 1.5 & -352.314 & 368.664 & 60.72 & 94.9 & 125.3 \\
\hline 2 & -362.610 & 349.341 & 62.78 & 74.4 & 130.7 \\
\hline 2.5 & -409.536 & 261.968 & 72.09 & 66.4 & 152.1 \\
\hline 3 & -419.674 & 149.541 & 84.07 & 65.8 & 243.5 \\
\hline c. Blanc & -315.256 & 1363.96 & - & 66 & 172.8 \\
\hline 0.5 & -344.327 & 766.907 & 43.77 & 79.6 & 135.4 \\
\hline 1 & -350.192 & 655.963 & 51.91 & 84.9 & 169.2 \\
\hline 1.5 & -365.322 & 335.15 & 75.43 & 62.4 & 143.7 \\
\hline 2 & -410.303 & 230.692 & 83.08 & 59.5 & 135.4 \\
\hline 2.5 & -425.814 & 174.901 & 87.17 & 58.8 & 117.8 \\
\hline 3 & -443.243 & 130.35 & 90.44 & 75.4 & 157.1 \\
\hline d. Blanc & -338.818 & 1061.61 & - & 92 & 159.6 \\
\hline 0.5 & -409.752 & 716.297 & 32.53 & 89.2 & 143.3 \\
\hline 1 & -419.102 & 502.708 & 52.65 & 77.2 & 204.3 \\
\hline 1.5 & -420.889 & 191.656 & 81.94 & 66.4 & 165.1 \\
\hline 2 & -437.547 & 166.246 & 84.34 & 74 & 187.2 \\
\hline 2.5 & -439.762 & 107.219 & 89.9 & 80.2 & 154.3 \\
\hline 3 & -457.644 & 92.703 & 91.27 & 83.8 & 156.6 \\
\hline
\end{tabular}

with those of other similar studies on the corrosion-inhibiting effect of plant extracts shows that our extracts are clearly more effective; Thus, El Attari et al. [84] recently carried out a study on the corrosion-inhibiting effect of the essential oil of Dysphania ambrosioides on steel in $1 \mathrm{M} \mathrm{HCl}$, and they found an inhibition efficiency of $90.20 \%$ at $4 \mathrm{~g} / \mathrm{l}$.

\subsection{Electrochemical Impedance Spectroscopy Results}

Nyquist diagrams of the steel immersed in the $\mathrm{HCl}$ acid solution without and with varied quantities added of $C$. siliqua extracts are shown in Fig. 4. The resulting impedance diagrams are not perfect semicircles, and this is attributed to the difference in frequency dispersion [85], due to the dissimilarity of the electrochemical system. This dissimilarity results from adsorption of the inhibitor, impurities, roughness, dislocations, and formation of porous layers $[86,87]$. When the concentration of all $C$. siliqua extracts increases from 0.5 to $3 \mathrm{~g} / \mathrm{l}$, it is noted that the increase in the size of the capacitive loop is well marked, which can be attributed to the load transfer process, and the impedance value obtained in the case of the control is lower than that obtained in the case of $C$. siliqua extracts. This result reflects the influence of these extracts on the process at the steel/acid interface. The electrochemical parameter's values and inhibitory efficiency for different concentrations of C. siliqua extracts for corrosion of steel in $\mathrm{HCl} 1 \mathrm{M}$ obtained by electrochemical impedance spectroscopy are presented in Table 5. The impedance results are simulated by the equivalent electrical circuit representative of the adsorption mechanism, illustrated in Fig. 5. This circuit consists of the constant phase element (CPE) which represents the frequency distributed in double capacitive layer, used to report the previously described inhomogeneities, the electrolyte resistance $\left(R_{\mathrm{s}}\right)$ which represents the ohmic fall in the electrolyte when a current passes between the working and reference electrode, and the load transfer resistance $\left(R_{\mathrm{ct}}\right)$.

Note that $\left(C_{\mathrm{dc}}\right)$ (double-layer capacity) and $\left(R_{\mathrm{ct}}\right)$ are introduced in parallel to show that at the interface level, the establishment of the double layer (modification of the distribution of electrical loads at the interface) and the transfer of load (electron transfer due to electrochemical reactions) are carried out simultaneously. Examination of the results in Table 5 indicates that the load transfer resistance $\left(R_{\mathrm{ct}}\right)$ values become more important with the increase in the concentration of $C$. siliqua extracts. The inhibitory efficiency $E(\%)$ of all the extracts studied, calculated from these parameters, evolves in the same way as the load transfer resistance, and reached a value of $89.32 \%$ and $92.04 \%$ for extracts (methanolic and aqueous) of C. siliqua with gallic acid, respectively. The results also show that the double-layer capacity $\left(C_{\mathrm{dc}}\right)$ decreases steadily as the inhibitor concentration rises. The same observation was carried out by GHAZI et al. [88] on the adsorption of the Peganum harmala methanolic extract on steel surface in $1 \mathrm{M} \mathrm{HCl}$. Better protection provided by an inhibitor is associated with a decrease in metal capacity [89]. This decline is linked to the adsorption of organic molecules on the surface of the steel [90]. Indeed, the thickness of the organic layer grows as the inhibitor adsorbs more, and the double layer's capacity decreases [91].

This trend is in agreement with the Helmholtz model, given by the following equation:

$C_{\mathrm{dc}}=\frac{\varepsilon \cdot \varepsilon_{0}}{d} \times A$,

where $d$ is the protective layer's thickness, $\varepsilon$ is the protective layer's dielectric constant, $\varepsilon_{0}$ is the environmental permittivity $\left(8.854 \times 10^{14} \mathrm{~F} / \mathrm{cm}\right)$, and $A$ is the electrode surface.

The inhibitor's adsorption to the steel's surface, therefore, reduces the medium's dielectric constant $\varepsilon$, and/or 
Fig. 4 Nyquist diagrams of steel in $1 \mathrm{M} \mathrm{HCl}$ containing different concentrations of $C$. siliqua extract: a extract of methanol without gallic acid; $\mathbf{b}$ extract of aqueous without gallic acid; c extract of methanol with gallic acid; $\mathbf{d}$ extract of aqueous with gallic acid
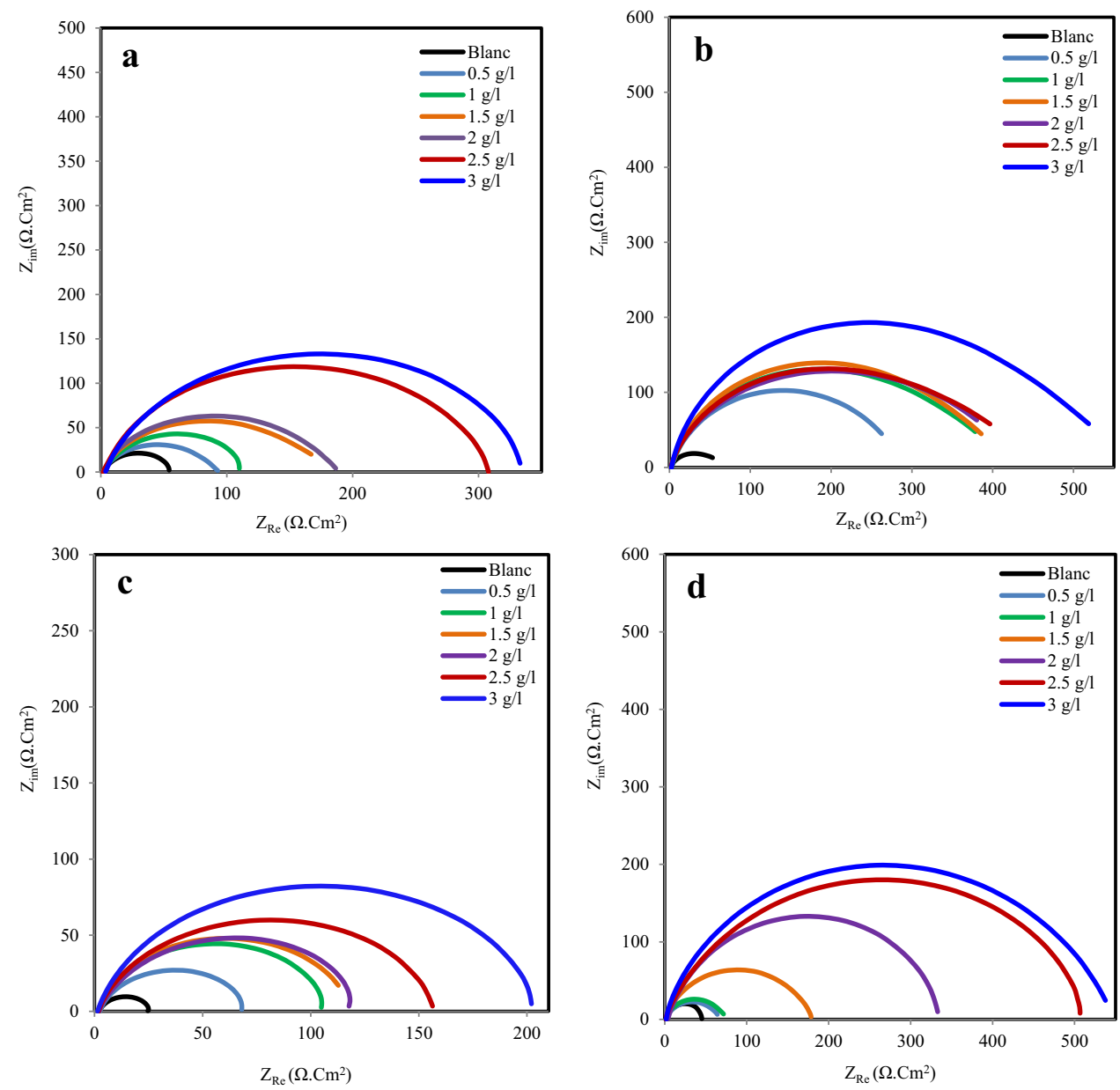

increases the double layer's thickness. The impedance study also confirmed the inhibitory character of all $C$. siliqua extracts obtained with mass loss measurements and polarization measurements.

\subsection{Adsorption Isotherm}

An isotherm is a function that describes the adsorbed quantity versus the concentration at a constant temperature. The pace of adsorption isotherms at a given temperature depends on the adsorbent/adsorbent interactions and in particular on the nature of the adsorbed species and the nature of the metal surface. An adsorption isotherm such as Langmuir is used in this study to describe the inhibition mechanism of $C$. siliqua extracts. Langmuir's adsorption isotherm is expressed by the following mathematical relationship:

$\frac{C_{\mathrm{inh}}}{\theta}=\frac{1}{K_{\mathrm{ads}}}+C_{\mathrm{inh}}$

With
$K_{\mathrm{ads}}=\frac{1}{C_{\mathrm{H}_{2} O}} \exp \left(-\frac{\Delta G_{\mathrm{ads}}^{\circ}}{R T}\right)$

where $C_{\text {inh }}$ is the inhibitor's concentration in the electrolyte; $K_{\text {ads }}$ is the constant of equilibrium of the adsorption process; $\theta$ is the degree of surface coverage $\mathrm{R}$ is the perfect gas constant $=8.314 \mathrm{~J} / \mathrm{K} / \mathrm{mol} ; T$ is the temperature and $C_{H 2 \mathrm{O}}$ is the water concentration and $\Delta \mathrm{G}_{\mathrm{ads}}^{\circ}$ is the standard-free adsorption energy.

Figure 6 illustrates this procedure and shows $C_{\text {inh }} / \theta$ versus of concentration for different temperatures. It can be seen that this representation gives straight lines with correlation coefficients greater than 0.98 and slope values are equal to 1 for all $C$. siliqua extracts. This shows that the adsorption of these extracts on the steel surface in $\mathrm{HCl}$ acid medium follows Langmuir's isotherm of adsorption. The same results were observed in the testing of henna extract used as a mild steel corrosion inhibitor in $\mathrm{HCl} 1 \mathrm{M}$ [17].

The equilibrium constant's values $\left(K_{\text {ads }}\right)$ were given in Table $6,\left(K_{\mathrm{ads}}\right)$ is related to the free adsorption energy standard $\left(\Delta G_{\mathrm{ads}}^{\circ}\right)$ by the following equation: 
Table 5 Electrochemical parameters for different concentrations of $C$. siliqua extract obtained by electrochemical impedance method in $1 \mathrm{M}$ $\mathrm{HCl}$ : a-extract of methanol without gallic acid; b-extract of aqueous without gallic acid; c-extract of methanol with gallic acid; d-extract of aqueous with gallic acid

\begin{tabular}{|c|c|c|c|c|}
\hline $\mathrm{C}(\mathrm{g} / \mathrm{l})$ & $R_{S}\left(\Omega \mathrm{Cm}^{2}\right)$ & $R_{c t}\left(\Omega \mathrm{Cm}^{2}\right)$ & $C_{d c}\left(\mu \mathrm{F} / \mathrm{Cm}^{2}\right)$ & $E(\%)$ \\
\hline a. Blanc & 2.599 & 51.08 & 148.3 & - \\
\hline 0.5 & 1.727 & 95.88 & 89.17 & 46.72 \\
\hline 1 & 2.223 & 111.4 & 68.29 & 54.15 \\
\hline 1.5 & 1.207 & 193.3 & 60.46 & 73.57 \\
\hline 2 & 1.079 & 200.3 & 57.48 & 74.49 \\
\hline 2.5 & 1.864 & 309.5 & 49.4 & 83.49 \\
\hline 3 & 3.661 & 340.1 & 41.74 & 84.98 \\
\hline b. Blanc & 1.762 & 65.85 & 439.9 & - \\
\hline 0.5 & 2.327 & 281.2 & 107.8 & 76.58 \\
\hline 1 & 2.491 & 387.3 & 111 & 82.99 \\
\hline 1.5 & 1.899 & 393.5 & 100.1 & 83.26 \\
\hline 2 & 1.746 & 394.4 & 98.47 & 83.3 \\
\hline 2.5 & 1.86 & 396.2 & 88.49 & 83.37 \\
\hline 3 & 2.474 & 497.2 & 88.42 & 86.75 \\
\hline c. Blanc & 2.327 & 21.74 & 126.4 & - \\
\hline 0.5 & 2.587 & 65.49 & 61.57 & 66.8 \\
\hline 1 & 1.578 & 108 & 60.77 & 79.87 \\
\hline 1.5 & 1.629 & 117.5 & 50.25 & 81.49 \\
\hline 2 & 1.927 & 122.4 & 47.99 & 82.24 \\
\hline 2.5 & 1.985 & 154.2 & 47.25 & 85.9 \\
\hline 3 & 1.391 & 203.7 & 45.36 & 89.32 \\
\hline d. Blanc & 2.506 & 42.23 & 177.5 & - \\
\hline 0.5 & 1.578 & 72.07 & 126.4 & 41.4 \\
\hline 1 & 1.261 & 94.67 & 89.17 & 55.39 \\
\hline 1.5 & 1.875 & 189.5 & 79.46 & 77.71 \\
\hline 2 & 1.661 & 340.1 & 46.31 & 87.58 \\
\hline 2.5 & 1.914 & 500.8 & 41.74 & 91.57 \\
\hline 3 & 1.599 & 530.4 & 39.64 & 92.04 \\
\hline
\end{tabular}

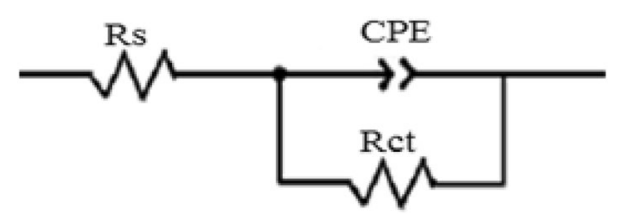

Fig. 5 Equivalent electrical circuit

$\Delta G_{\text {ads }}^{\circ}=-R T \operatorname{Ln}\left(C_{\mathrm{H}_{2} \mathrm{O}} \cdot K_{\mathrm{ads}}\right)$

From this equation, $\left(\Delta G_{\mathrm{ads}}^{\circ}\right)$ values at all studied temperatures can be calculated.

In this equation, $\mathrm{C}_{\mathrm{H} 2 \mathrm{O}}$ is used in $\mathrm{g} / \mathrm{l}, K_{\mathrm{ads}}$ in $1 / \mathrm{g}$, so the adsorption $\left(\Delta G_{\mathrm{ads}}^{\circ}\right)$ unit depends only on the $\mathrm{R} \times \mathrm{T}$ factor $(\mathrm{kJ} / \mathrm{mol})$. The values obtained from $\left(\Delta G_{\mathrm{ads}}^{\circ}\right)$ are given in
Table 6. $\left(\Delta H_{\mathrm{ads}}^{\circ}\right)$ and $\left(\Delta S_{\mathrm{ads}}^{\circ}\right)$ values are determined from the following equation:

$\Delta G_{\mathrm{ads}}^{\circ}=\Delta H_{\mathrm{ads}}^{\circ}-T \Delta S_{\mathrm{ads}}^{\circ}$

Figure 7 demonstrates the change in $\left(\Delta G_{\text {ads }}^{\circ}\right)$ versus $T$. The resulting lines have the slope $\left(\Delta S_{\mathrm{ads}}^{\circ}\right)$, while $\left(\Delta H_{\mathrm{ads}}^{\circ}\right)$ its ordinate at the origin. The adsorption parameters collected in Table 6, clarify the chemical interaction between natural extract with the metal surface. In general, two types of adsorption might be considered: physical adsorption or chemical adsorption, and sometimes both at the same time.

$\left(\Delta G_{\text {ads }}^{\circ}\right)$ values are negative at the temperatures studied for all $C$. siliqua extracts, indicating that the $C$. siliqua adsorption process occurs spontaneously [92]. Exothermic adsorption $\left(\Delta H_{\mathrm{ads}}^{\circ}<0\right)$ may involve physical adsorption and/or chemisorption, While an endothermic adsorption process $\left(\Delta H_{\mathrm{ads}}^{\circ}>0\right)$ is attributed to chemisorptions [93]. Physisorption differs from chemisorption in an exothermic process by taking into account the absolute value of $\left(\Delta H_{\mathrm{ads}}^{\circ}\right)$. When the value is less than $40 \mathrm{~kJ} / \mathrm{mol}$, it is a physisorption and if the value of $\left(\Delta H_{\text {ads }}^{\circ}\right)$ is close to $100 \mathrm{~kJ} /$ mol, it is a chemisorptions [94]. In this work, the values of $\left(\Delta H_{\text {ads }}^{\circ}\right)$ obtained for extracts (aqueous and methanolic) of $C$. siliqua show that exothermic adsorption can occur, so physical adsorption has been detected. However, the calculated values of $\left(\Delta H_{\mathrm{ads}}^{\circ}\right)$ for extracts (aqueous and methanolic) of $C$. siliqua with presence of gallic acid are 20.985 and $13.547 \mathrm{~kJ} / \mathrm{mol}$, respectively, indicating the chemisorbed nature on metallic surface. The higher value of $\left(\Delta H_{\text {ads }}^{\circ}\right.$ ) for aqueous extract of $C$. silqua with gallic acid indicates that it is more adsorbed than the methanolic extract of $C$. siliqua with gallic acid on the metallic surface. This corresponds to the findings of weight loss measurements, polarization curves, and impedance. The values of $\left(\Delta S_{\text {ads }}^{\circ}\right)$ obtained for extracts (aqueous and methanolic) of $C$. siliqua with gallic acid are high and positive, reflecting an increase in the disorder that occurs during the formation of the metal complex/adsorbed species [95]. The evolution of $\left(\Delta G_{\text {ads }}^{\circ}\right)$ versus temperature is linear for all the extracts studied, indicating a good correlation between the thermodynamic parameters.

\subsection{Kinetic/Thermodynamics Considerations}

Temperature is a significant factor in the study of metal dissolution. For example, the rate of corrosion in acidic solutions grows exponentially as the temperature rises. The mechanism of action of an inhibitor can be achieved by comparing the apparent activation energies $\left(E_{\mathrm{a}}\right)$ in the presence and absence of $C$. siliqua extracts. The Arrhenius formula is presented by 
Fig. 6 Langmuir's isotherm of adsorption of $C$. siliqua extract on carbon steel in $\mathrm{HCl} 1 \mathrm{M}$ at different temperatures: a extract of methanol without gallic acid; b extract of aqueous without gallic acid; $\mathbf{c}$ extract of methanol with gallic acid; $\mathbf{d}$ extract of aqueous with gallic acid

Table 6 Thermodynamic parameters of $C$. siliqua extract in $\mathrm{HCl} 1 \mathrm{M}$ for different temperatures: a-extract of methanol without gallic acid; b-extract of aqueous without gallic acid; c-extract of methanol with gallic acid; d-extract of aqueous with gallic acid
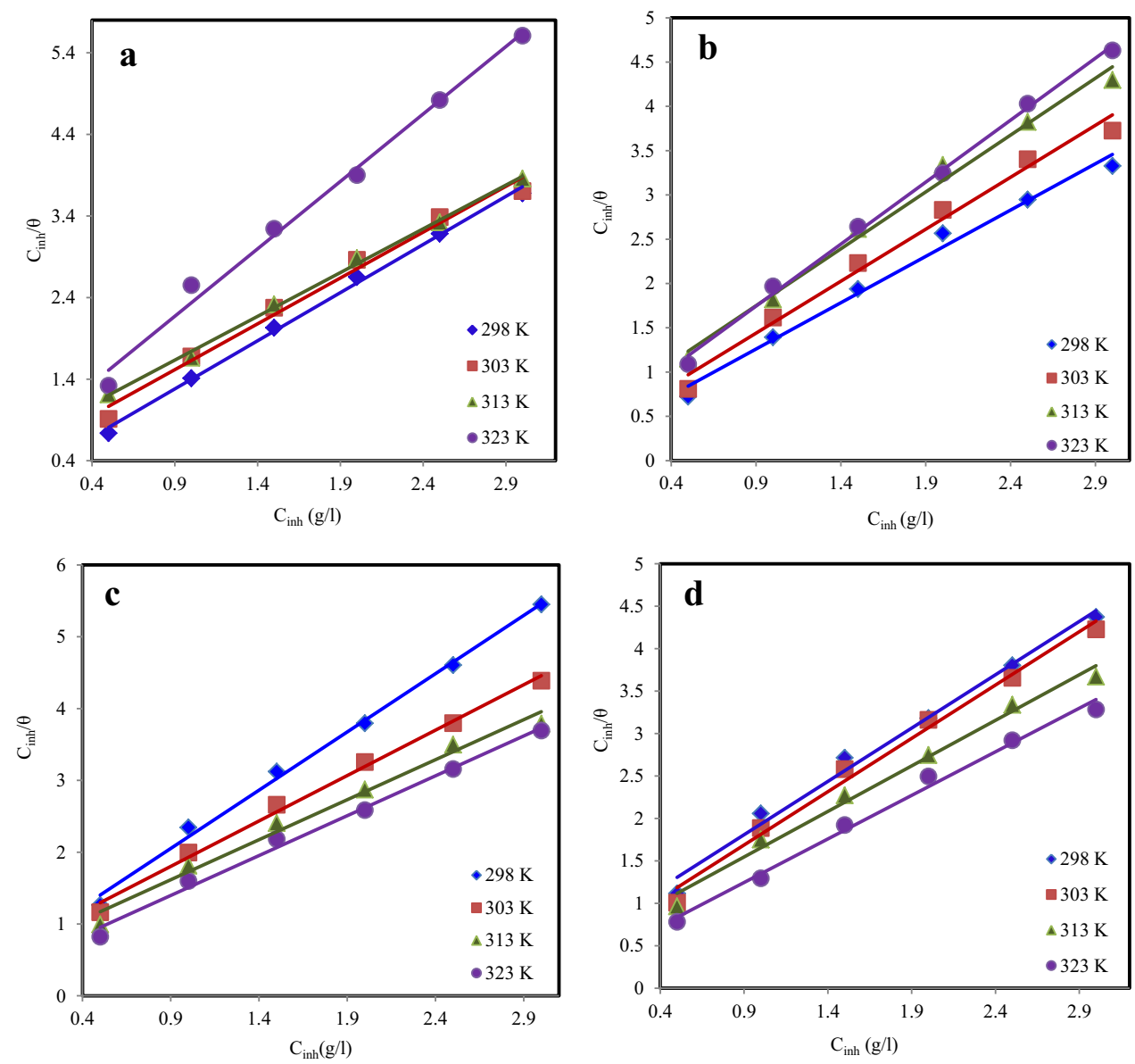

\begin{tabular}{llllll}
\hline $\mathrm{T}(\mathrm{K})$ & $K_{\text {ads }}(1 / \mathrm{g})$ & $\Delta G_{\text {ads }}^{\circ}(\mathrm{kJ} / \mathrm{mol})$ & $R^{2}$ & $\Delta H_{\text {ads }}^{\circ}(\mathrm{kJ} / \mathrm{mol})$ & $\Delta S_{\text {ads }}^{\circ}(\mathrm{J} / \mathrm{mol} / \mathrm{K})$ \\
\hline a. 298 & 4.57 & -20.88 & 0.9969 & & -35.70 \\
303 & 1.98 & -19.12 & 0.9857 & & -40.92 \\
313 & 1.49 & -19.01 & 0.9972 & -31.520 & -39.97 \\
323 & 1.46 & -19.56 & 0.9919 & & -37.03 \\
b. 298 & 3.14 & -19.95 & 0.9879 & & 16.72 \\
303 & 2.61 & -19.82 & 0.986 & & 16.01 \\
313 & 1.68 & -19.32 & 0.9899 & -14.968 & 13.9 \\
323 & 2.06 & -20.49 & 0.997 & & 17.09 \\
c. 298 & 1.68 & -18.39 & 0.9958 & & 107.17 \\
303 & 1.5 & -18.42 & 0.9941 & & 105.5 \\
313 & 1.62 & -19.23 & 0.9833 & 13.547 & 107.02 \\
323 & 2.51 & -21.02 & 0.9924 & & 131.06 \\
d. 298 & 1.47 & -18.07 & 0.9885 & & 131.57 \\
303 & 1.8 & -18.88 & 0.9891 & & 128.96 \\
313 & 1.72 & -19.38 & 0.9878 & 20.985 & 131.81 \\
323 & 3.11 & -21.59 & 0.9917 & & \\
\hline
\end{tabular}

$L n(w)=\operatorname{Ln}(A)-\frac{E_{\mathrm{a}}}{R T}$

with $A$ is Arrhenius factor (pre-exponential).
The variation curves of $\operatorname{Ln}(w)$ as a function of $(1000 / T)$ for the $C$. siliqua extracts are given in Fig. 8. These are straight lines, thus, showing that the law of Arrhenius applies to describe the kinetics of the adsorption of 
Fig. 7 Variation of $\Delta G_{\text {ads }}^{\circ}$ versus $T:$ a extract of methanol without gallic acid; $\mathbf{b}$ extract of aqueous without gallic acid; $\mathbf{c}$ extract of methanol with gallic acid; $\mathbf{d}$ extract of aqueous with gallic acid
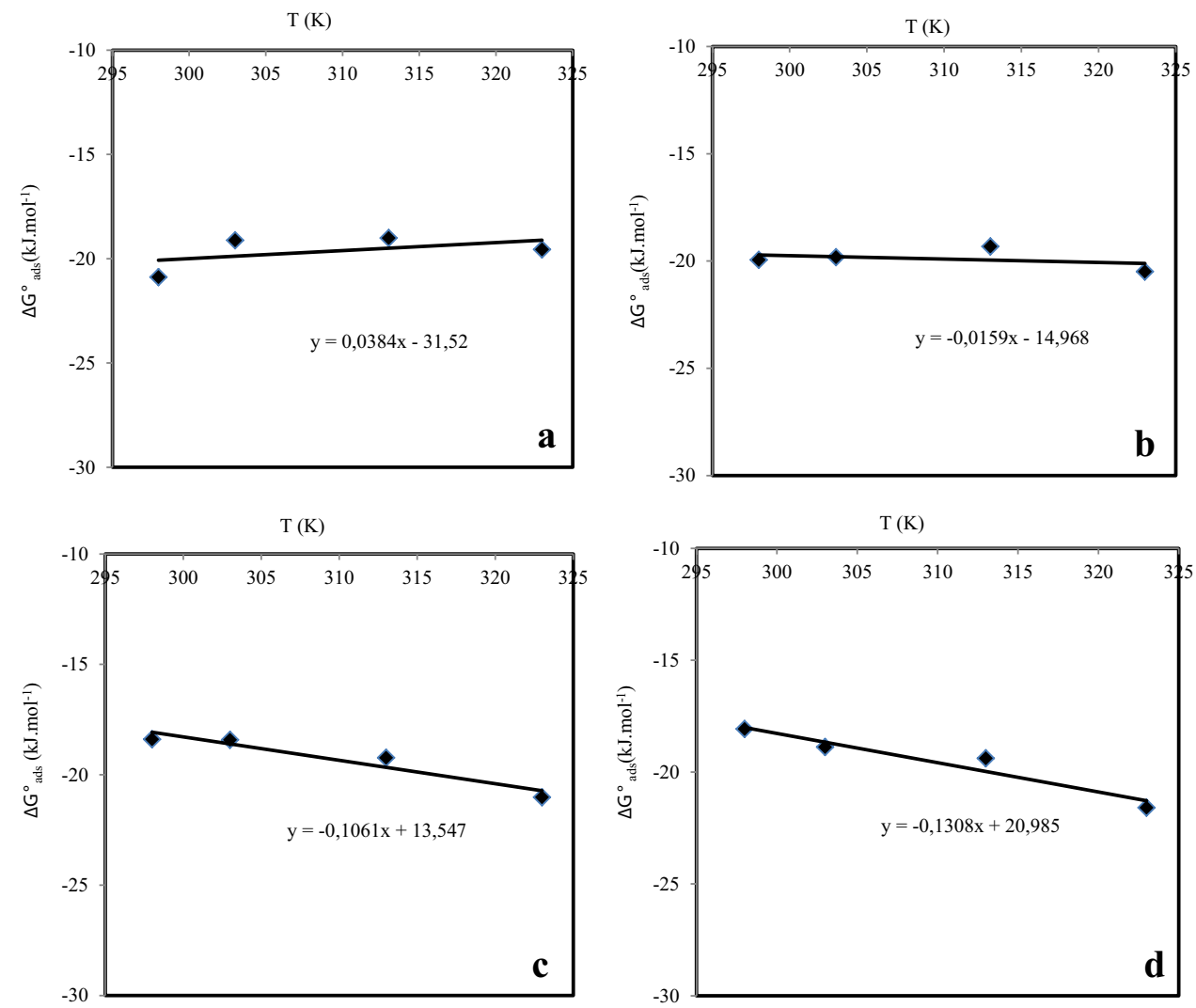

inhibitor on the surface of the steel. Activation enthalpy $\left(\Delta H_{\mathrm{a}}^{*}\right)$ and the activation entropy $\left(\Delta S_{\mathrm{a}}^{*}\right)$ in the transition state for the intermediate complex of corrosion from carbon steel in $\mathrm{HCl}$, without and with different concentrations of $C$. siliqua extracts, were achieved by utilizing the following transition state equation:

$\log \left(\frac{w}{T}\right)=\left[\left(\log \left(\frac{R}{h N}\right)\right)+\frac{\Delta S *}{2303 R}\right]-\frac{\Delta H *}{2303 R T}$.

The variation of $\operatorname{Ln}(w / T)$ versus the inverse of the temperature $(1000 / T)$ is presented by straight lines (Fig. 9), where $\left(\Delta H_{\mathrm{a}}^{*} / \mathrm{R}\right)$ is the slope of the line and $\log (\mathrm{R} / \mathrm{hN})$ $+\Delta S_{\mathrm{a}}^{*} / \mathrm{R}$ is the ordinate at the origin. These two expressions make it possible to calculate the activation parameters, $\left(\Delta H_{\mathrm{a}}^{*}\right)$ and $\left(\Delta S_{\mathrm{a}}^{*}\right)$, of which values are collected in Table 7.

It is noted from Table 7 that the values of $\left(E_{\mathrm{a}}\right)$ are more than that of blank and increase with the concentration for extracts (aqueous and methanolic) of $C$. siliqua. When $\left(E_{\mathrm{a}}\right)$ with inhibitor presence is greater than the blank value, this phenomenon is commonly seen as a result of physisorption, this result is consistent with the literature data [96]. Analysis of temperature's influence on protection efficiencies $\mathrm{E}(\%)$ (Table 3) shows that inhibition efficiencies for extracts (aqueous and methanolic) of $C$. siliqua decrease with temperature increase. This is related to a decline in the adsorption of these extracts at higher temperatures. This confirms that physical adsorption could be the sort of adsorption on the metal surface. These results appear to be consistent with other research that showed that an increase in $\left(E_{\mathrm{a}}\right)$ with inhibitor concentration was associated with the physisorption mechanism [97]. However, in our study, the data show that the values of $\left(E_{\mathrm{a}}\right)$ are lower than that of blank in the event of extracts (aqueous and methanolic) of $C$. siliqua in the presence of gallic acid. The concentration rises leads to a decrease in activation energy. This decrease is attributed to the substantial increase in the adsorption capability of the inhibitor on a metallic surface with the decrease in corrosion rate [98], this indicates that the inhibitory action of these $C$. siliqua extracts occurs by chemical adsorption. For extracts (aqueous and methanolic) of $C$. siliqua, it is observed that the $\left(\Delta S_{\mathrm{a}}^{*}\right)$ values evolve towards more positive values. This leads to more disorderly behavior. Moreover, in the case of extracts (aqueous and methanolic) of $C$. siliqua in the gallic acid presence, the values evolve towards more negative values (more ordered behavior). This can be explained by the involvement of the constituents of these extracts in the activated complex of the corrosion reaction, which leads to a more ordered system [99]. For all studied concentrations of $C$. siliqua extracts, the mean value of the $E_{\mathrm{a}}-\Delta H_{\mathrm{a}}^{*}$ difference is around $2.57 \mathrm{~kJ} / \mathrm{mol}$, which corresponds to the mean value of $R \times T$, indicating that the corrosion reaction is a 
Fig. 8 Arrhenius straight lines at different temperatures: a extract of methanol without gallic acid; $\mathbf{b}$ extract of aqueous without gallic acid; c extract of methanol with gallic acid; $\mathbf{d}$ extract of aqueous with gallic acid
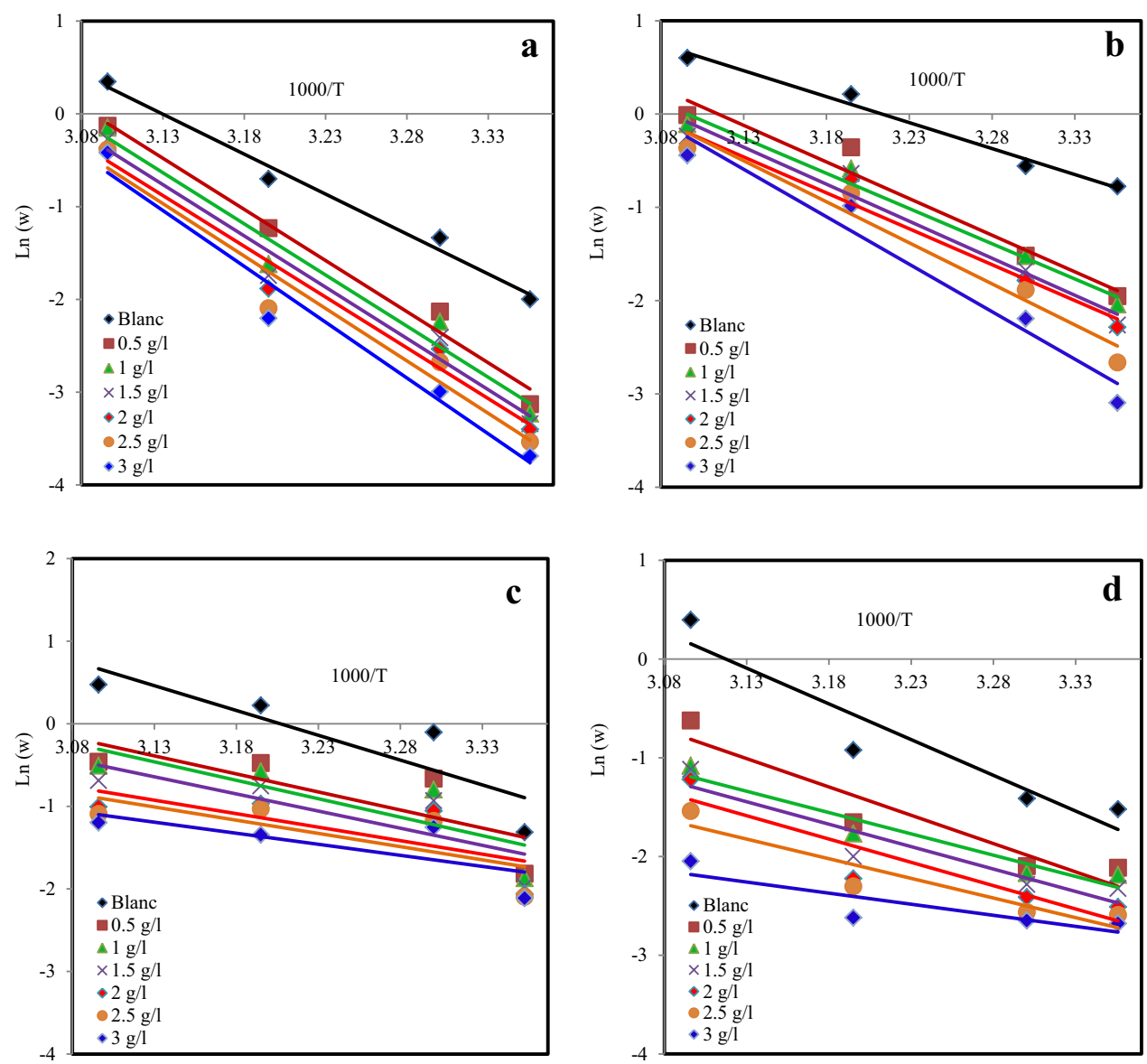

monomolecular reaction [100]. These results are in agreement with the studies carried out on the plant extracts [101, 102].

\subsection{Fourier Transform Infrared Spectroscopy (FTIR) Studies}

The FTIR spectra of $1 \mathrm{M} \mathrm{HCl}+3 \mathrm{~g} / \mathrm{l}$ of the methanolic and aqueous extracts of $C$. siliqua before and after the corrosion tests are presented in Fig. 10. A summary of these results is given in Table 8 . The spectra revealed that all extracts had nearly identical peaks; however, after the corrosion test, the intensities reduced or increased when these compounds reacted with the metal and acid to generate corrosion products [103]. A broad band at $3300 / 3327 \mathrm{~cm}^{-1}$ and $3334 / 3328 \mathrm{~cm}^{-1}$ can be attributed to the stretching vibration $(\mathrm{O}-\mathrm{H})$ before/after the corrosion test for the methanolic and aqueous extracts respectively. In the methanolic extract, a small peak at $2932 \mathrm{~cm}^{-1}$ was observed for the pure extract corresponding to a stretching vibration $(\mathrm{C}-\mathrm{H})$ in the $-\mathrm{CH}_{2}$ group. Such a peak can be attributed to the stretching vibration of the carbonyl groups $(\mathrm{C}=\mathrm{O})$, and its intensity was shifted from 1635 to $1627 \mathrm{~cm}^{-1}$ after testing for the methanolic extract and from 1632 to $1633 \mathrm{~cm}^{-1}$ for the aqueous extract indicates the formation of an iron-plant extract complex [104]. Before the corrosion test in the methanolic extract, a peak appears at $1050 \mathrm{~cm}^{-1}$ which could be attributed to stretching vibrations $(\mathrm{C}-\mathrm{O})$ in the primary alcohol. However, this peak was increased for the pure extract and its intensity decreased after the corrosion test. The stretching vibration $(\mathrm{C}-\mathrm{O})$ in tertiary alcohol was observed at $1193 \mathrm{~cm}^{-1}$ before the test in the methanolic extract and disappeared in the FTIR spectra after the corrosion test, whereas in the extract aqueous, two peaks appear at 1160 and $1033 \mathrm{~cm}^{-1}$; can be related to the stretching vibration of $(\mathrm{C}-\mathrm{O})$ and disappear after the corrosion test; and reveals that oxygen atoms can act as active adsorption centers. Double peaks around $500 / 1000 \mathrm{~cm}^{-1}$ are related to stretching vibrations $(\mathrm{C}-\mathrm{H})$ in aromatic rings for three tests. Thus, the results showed that $C$. siliqua extracts contain organic molecules rich in oxygen atoms as well as aromatic rings, such as phenols, which meet the basic requirements of a good inhibitor [105].

\subsection{X-ray Diffraction Studies}

The X-ray diffraction (XRD) patterns of the prepared steel surface before and after immersion in $1 \mathrm{M} \mathrm{HCl}$, without and 
Fig. 9 Variation of $\operatorname{Ln}(w / T)$ in the inverse of the temperature without and with $C$. siliqua extract: a extract of methanol without gallic acid; $\mathbf{b}$ extract of aqueous without gallic acid; $\mathbf{c}$ extract of methanol with gallic acid; $\mathbf{d}$ extract of aqueous with gallic acid
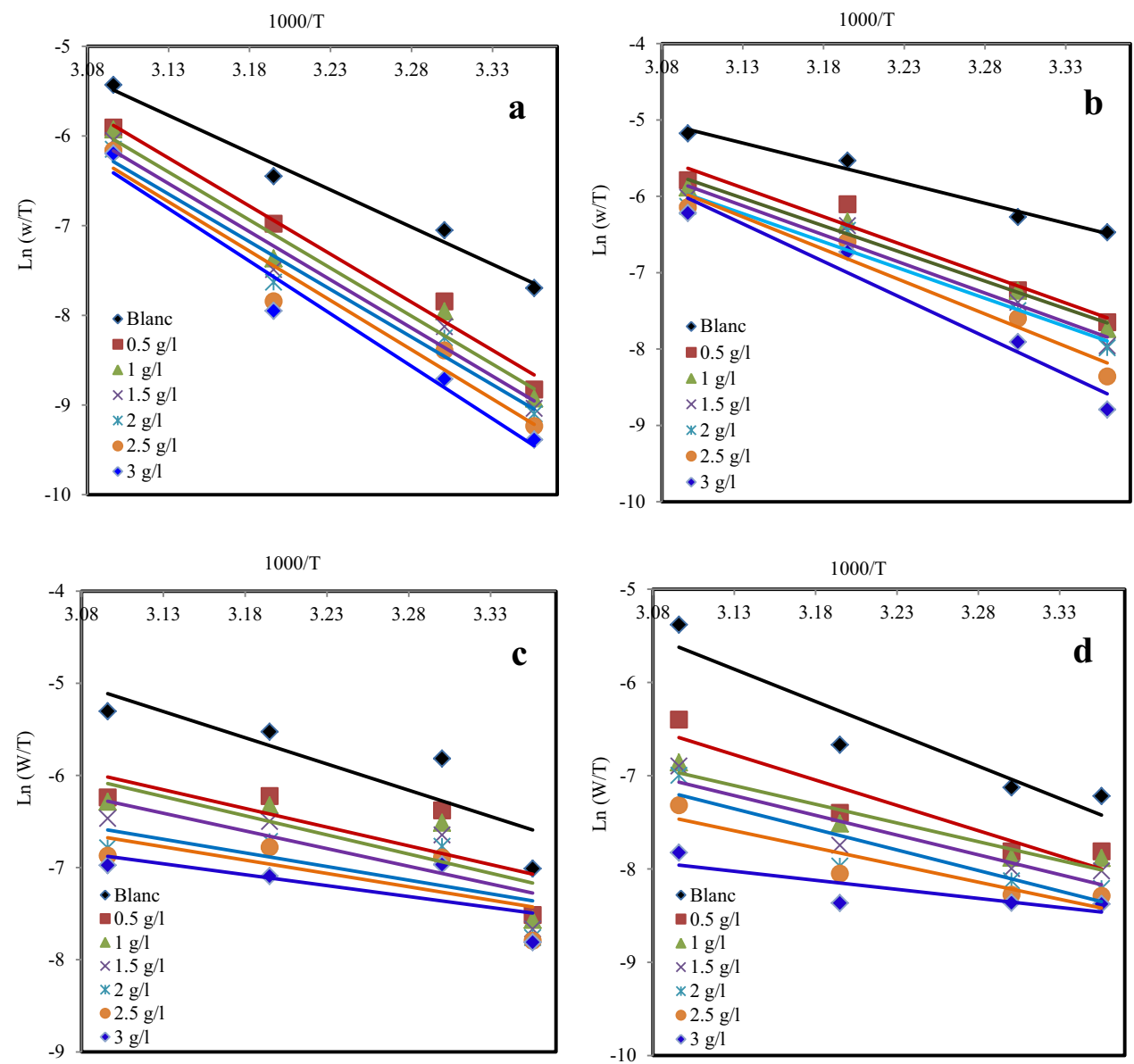

with the aqueous extract of $C$. siliqua in the absence and presence of gallic acid are shown in Fig. 11.

Similarly, the peak list of the XRD patterns of the prepared steel before and after immersion in $1 \mathrm{M} \mathrm{HCl}$ without and with the aqueous extract of $C$. siliqua in the absence and presence of gallic acid are highlighted in Table 9, while Table 10 shows the identified Patterns list of the phases obtained from the XRD Patterns of the steel without $\mathrm{HCl}$ and steel immersed in $1 \mathrm{M} \mathrm{HCl}$ both in the absence and presence of the aqueous extract of $C$. siliqua without and with gallic acid.

By analyzing the spectra obtained, we note the presence of two lines in the spectrum recorded without immersion of $\mathrm{HCl}$ acid $\left(2 \theta=45.0435^{\circ}\right.$ and $\left.65.1878^{\circ}\right)$, the identification of these two lines is done by comparing the experimental data with the reference data that constitute the code file. This study shows that the diffraction lines are those characteristics of iron, which does the main element constitute the Carbon steel sample according to the standard file (COD 96-900-6598), while during the immersion of the steel in $\mathrm{HCl}$ in the absence of the extract, the intensity corresponding to the peak of iron towards $\left(2 \theta=65.2577^{\circ}\right)$ was decreased $(8.16 \%)$; so, we note the appearance of iron oxide $\left(\mathrm{Fe}_{24} \mathrm{O}_{32}\right)$ at $65.2577^{\circ}$ according to the standard file
(COD 96-900-2332) as well as the appearance of peaks at $\left(21.9281^{\circ}\right.$ and $\left.33.7206^{\circ}\right)$ suggesting the presence of iron oxides $\left(\mathrm{Fe}_{4} \mathrm{O}_{8}\right)$ according to the standard file (COD 96-9003081), i.e., corrosion products resulting from the deterioration and degradation of the steel sample. The presence of inhibitor without gallic acid indicates a lower presence of corrosion products in $\mathrm{HCl}$; however, the introduction of the extract with gallic acid reveals the complete absence of the iron oxides. This observation is due to the inhibitive effect of the extract of $C$. siliqua with gallic acid. Therefore, the extract effectively aided the passivation of the steel and minimized the chemical reaction involving the diffusion of the anodic and cathodic species [106].

\subsection{Scanning Electron Microscope (SEM) and Energy Dispersive X-ray Spectroscopy (EDS) Studies}

Scanning electron microscope (SEM) images were taken in order to study the surface morphology of carbon steel in the absence and presence of inhibitor. SEM/EDS micrographs obtained for carbon steel surface before and after immersion in $1 \mathrm{M} \mathrm{HCl}$, without and with $3 \mathrm{~g} / \mathrm{l}$ of $C$. siliqua aqueous extract in the absence and presence of gallic acid are shown in Fig. 12. 
Table 7 Thermodynamic parameters of activation of $C$. siliqua extract in $1 \mathrm{M} \mathrm{HCl}$ : a-extract of methanol without gallic acid; b-extract of aqueous without gallic acid; c-extract of methanol with gallic acid; d-extract of aqueous with gallic acid

\begin{tabular}{|c|c|c|c|c|c|}
\hline $\mathrm{C}(\mathrm{g} / \mathrm{l})$ & $\mathrm{A}\left(\mathrm{mg} / \mathrm{cm}^{2} / \mathrm{h}^{1}\right)$ & $E_{\mathrm{a}}(\mathrm{kJ} / \mathrm{mol})$ & $\Delta H_{\mathrm{a}}^{*}(\mathrm{~kJ} / \mathrm{mol})$ & $\Delta S_{\mathrm{a}}^{*}(\mathrm{~J} / \mathrm{k} / \mathrm{mol})$ & $\begin{array}{l}E_{\mathrm{a}}-\Delta H_{\mathrm{a}}^{*} \\
(\mathrm{~kJ} / \mathrm{mol})\end{array}$ \\
\hline a. Blanc & $5.07 \times 10^{11}$ & 71.59 & 69.0203 & -29.4872 & 2.57 \\
\hline 0.5 & $5.97 \times 10^{14}$ & 91.64 & 89.0678 & 29.3094 & 2.57 \\
\hline 1 & $5.05 \times 10^{14}$ & 91.62 & 89.0429 & 27.9209 & 2.57 \\
\hline 1.5 & $4.96 \times 10^{14}$ & 91.91 & 89.3256 & 27.7629 & 2.58 \\
\hline 2 & $3.08 \times 10^{14}$ & 90.95 & 88.3778 & 23.8138 & 2.57 \\
\hline 2.5 & $8.80 \times 10^{14}$ & 93.97 & 91.3958 & 32.5269 & 2.57 \\
\hline 3 & $7.99 \times 10^{15}$ & 100.03 & 97.4484 & 50.8676 & 2.58 \\
\hline b. Blanc & $5.87 \times 10^{7}$ & 46.28 & 43.7025 & -104.837 & 2.57 \\
\hline 0.5 & $4.16 \times 10^{10}$ & 65.27 & 62.69 & -50.2805 & 2.58 \\
\hline 1 & $1.41 \times 10^{10}$ & 62.76 & 60.1792 & -59.2763 & 2.58 \\
\hline 1.5 & $4.28 \times 10^{10}$ & 65.97 & 63.3926 & -50.0311 & 2.57 \\
\hline 2 & $1.84 \times 10^{10}$ & 64.01 & 61.4288 & -57.0398 & 2.58 \\
\hline 2.5 & $5.46 \times 10^{11}$ & 73.12 & 70.5393 & -28.8719 & 2.58 \\
\hline 3 & $3.71 \times 10^{13}$ & 84.57 & 81.9926 & 6.2214 & 2.58 \\
\hline c. Blanc & $2.32 \times 10^{8}$ & 49.95 & 47.3673 & -93.4052 & 2.58 \\
\hline 0.5 & $5.90 \times 10^{5}$ & 36.33 & 33.749 & -143.0839 & 2.58 \\
\hline 1 & $7.46 \times 10^{5}$ & 37.15 & 34.5696 & -141.1293 & 2.58 \\
\hline 1.5 & $2.31 \times 10^{5}$ & 34.51 & 31.9365 & -50.8749 & 2.57 \\
\hline 2 & $1.10 \times 10^{4}$ & 27.18 & 24.6019 & -176.1803 & 2.58 \\
\hline 2.5 & $8.22 \times 10^{3}$ & 26.62 & 24.0441 & -178.6121 & 2.57 \\
\hline 3 & $1.32 \times 10^{3}$ & 22.26 & 19.6809 & -193.7976 & 2.58 \\
\hline d. Blanc & $6.39 \times 10^{9}$ & 60.21 & 57.6376 & -65.84430 & 2.57 \\
\hline 0.5 & $2.33 \times 10^{7}$ & 47.74 & 45.1591 & -112.5274 & 2.58 \\
\hline 1 & $1.96 \times 10^{5}$ & 35.92 & 33.3416 & -152.2609 & 2.58 \\
\hline 1.5 & $3.54 \times 10^{5}$ & 37.78 & 35.2006 & -147.3340 & 2.58 \\
\hline 2 & $5.36 \times 10^{5}$ & 39.25 & 36.6764 & -143.8895 & 2.57 \\
\hline 2.5 & $4.15 \times 10^{4}$ & 33.09 & 30.509 & -165.1617 & 2.58 \\
\hline 3 & $1.18 \times 10^{2}$ & 18.68 & 16.105 & -213.8576 & 2.57 \\
\hline
\end{tabular}

Fig. 10 FTIR spectrum of $C$. siliqua extract pure before and after corrosion test: a extract of methanol; $\mathbf{b}$ extract of aqueous
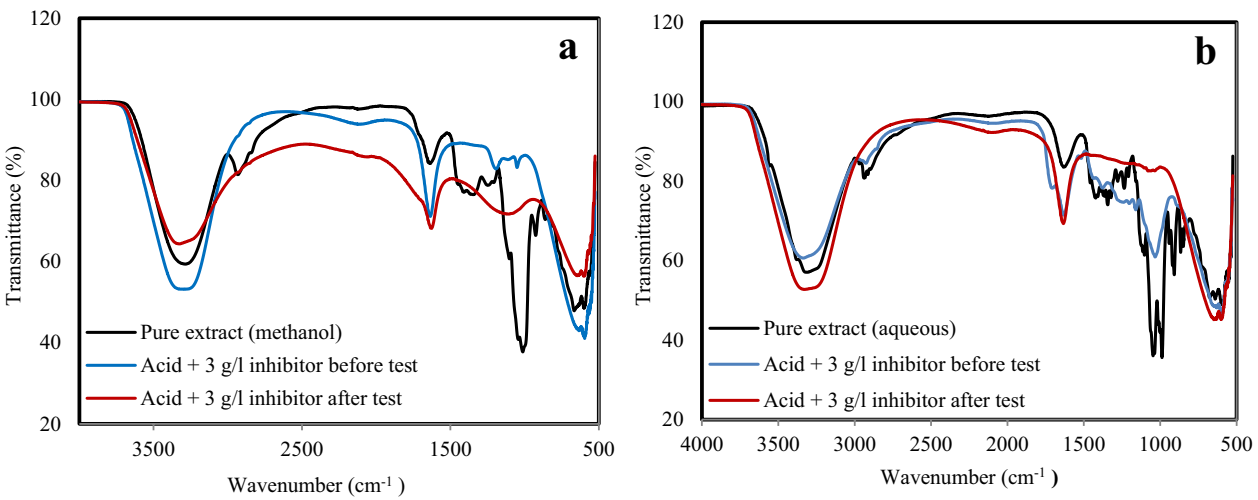

The surface morphology of the carbon steel sample was examined by SEM/EDS after $6 \mathrm{~h}$ of immersion in $1 \mathrm{M}$ $\mathrm{HCl}$ in the extract-free solution and also when the extract was introduced. Figure 12a shows a freshly polished (asreceived) surface of the steel that is very smooth and not corroded but with minor scratches due to polishing operation. The associated SEM of Fig. 12b (without extract) reveals a surface that is rapidly attacked and heavily damaged with evidence of cracks, pits, and/or cavities which simply affirms metallic dissolution in the stated medium due to the pitting action of chloride ions. By comparison of SEM images, it can be noted from Fig. 12c, d that it exhibits a reduction in corrosion attack. This reduction is more observed in SEM images of samples immersed in the presence of gallic acid 
Table 8 Characteristic peaks obtained from FTIR spectra for $1 \mathrm{M} \mathrm{HCl}+$ C. siliqua solution before and after corrosion test: a-extract of methanol; b-extract of aqueous

\begin{tabular}{|c|c|c|c|c|c|}
\hline \multicolumn{2}{|l|}{ Pure extract } & \multicolumn{2}{|c|}{$1 \mathrm{M} \mathrm{HCl}+3 \mathrm{~g} / \mathrm{l}$ inhibitor before test } & \multicolumn{2}{|c|}{$1 \mathrm{M} \mathrm{HCl}+3 \mathrm{~g} / \mathrm{l}$ inhibitor after test } \\
\hline a. Frequency $\left(\mathrm{cm}^{-1}\right)$ & Functional group & Frequency $\left(\mathrm{cm}^{-1}\right)$ & Functional group & Frequency $\left(\mathrm{cm}^{-1}\right)$ & Functional group \\
\hline 3287.92 & $\mathrm{O}-\mathrm{H}$ stretching & 3300.41 & $\mathrm{O}-\mathrm{H}$ stretching & 3327.64 & $\mathrm{O}-\mathrm{H}$ stretching \\
\hline 2932.3 & $\mathrm{C}-\mathrm{H}$ stretching & - & - & - & - \\
\hline 1634.05 & $\mathrm{C}=\mathrm{O}$ stretching & 1635.06 & $\mathrm{C}=\mathrm{O}$ stretching & 1627.66 & $\mathrm{C}=\mathrm{O}$ stretching \\
\hline- & - & 1193.13 & $\mathrm{C}-\mathrm{O}$ stretching & - & - \\
\hline 1347.06 & $\mathrm{C}-\mathrm{H}$ stretching & 1050.6 & $\mathrm{C}-\mathrm{O}$ stretching & 1111.5 & $\mathrm{C}-\mathrm{O}$ stretching \\
\hline 925.08 & $=\mathrm{C}-\mathrm{H}$ bending & - & - & - & - \\
\hline 665.49 & $=\mathrm{C}-\mathrm{H}$ bending & - & - & - & - \\
\hline 599.1 & $=\mathrm{C}-\mathrm{H}$ bending & 595.11 & $=\mathrm{C}-\mathrm{H}$ bending & 602.77 & $=\mathrm{C}-\mathrm{H}$ bending \\
\hline b. Frequency $\left(\mathrm{cm}^{-1}\right)$ & Functional group & Frequency $\left(\mathrm{cm}^{-1}\right)$ & Functional group & Frequency $\left(\mathrm{cm}^{-1}\right)$ & $\begin{array}{l}\text { Functional group } \\
\mathrm{O}-\mathrm{H} \text { stretching }\end{array}$ \\
\hline 3316.21 & $\mathrm{O}-\mathrm{H}$ stretching & 3334.99 & $\mathrm{O}-\mathrm{H}$ stretching & 3328.01 & - \\
\hline 2939.52 & $\mathrm{C}-\mathrm{H}$ stretching & - & - & - & $\mathrm{C}=\mathrm{O}$ stretching \\
\hline 1633.09 & $\mathrm{C}=\mathrm{O}$ stretching & 1632.77 & $\mathrm{C}=\mathrm{O}$ stretching & 1633.89 & - \\
\hline 1422.66 & $\mathrm{C}-\mathrm{C}$ stretching & - & - & - & - \\
\hline 1343.47 & $\mathrm{C}-\mathrm{H}$ bending & - & - & - & - \\
\hline 1103.41 & $\mathrm{C}-\mathrm{O}$ stretching & 1160.11 & $\mathrm{C}-\mathrm{O}$ stretching & - & - \\
\hline 1046.77 & $\mathrm{C}-\mathrm{O}$ stretching & 1033.63 & $\mathrm{C}-\mathrm{O}$ stretching & - & $=\mathrm{C}-\mathrm{H}$ bending \\
\hline 599.18 & $=\mathrm{C}-\mathrm{H}$ bending & 598.94 & $=\mathrm{C}-\mathrm{H}$ bending & 599.19 & \\
\hline
\end{tabular}

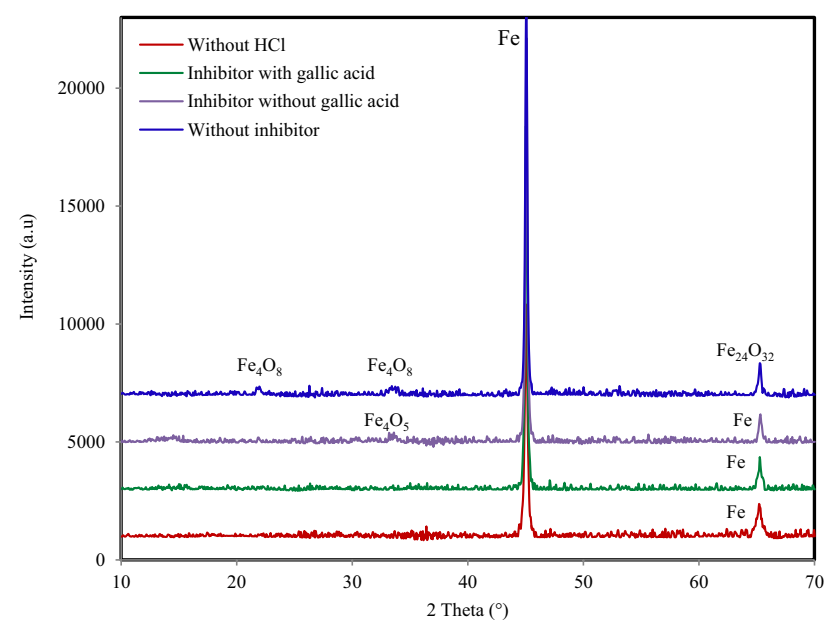

Fig. 11 XRD patterns of the steel surface before and after immersion in $1 \mathrm{M} \mathrm{HCl}$ in the absence and presence of aqueous extract of $C$. sili$q u a$ without and with gallic acid

(Fig. 12d) which is consistent with the previous tests that show a lower corrosion rate for the samples immersed in the presence of this additive.

The EDS analysis results of the carbon steel surface before and after immersion in $1 \mathrm{M} \mathrm{HCl}$ in the absence and presence of $C$. siliqua aqueous extract without and with gallic acid are shown in Fig. 12. Specifically, an EDS spectrum highlights the major elemental constituents at the surface
Table 9 Peak list obtained from the XRD Patterns of the steel: a-without $\mathrm{HCl}$; b-without inhibitor; c-presence of inhibitor without gallic acid; d-the presence of inhibitor with gallic acid

\begin{tabular}{lclll}
\hline Pos. $\left[{ }^{\circ}\right.$ 2Th.] & Height [cts] & $\begin{array}{l}\text { FWHM Left } \\
{\left[{ }^{\circ} 2 \text { Th. }\right]}\end{array}$ & $\begin{array}{l}\text { d-spacing } \\
{[\AA]}\end{array}$ & $\begin{array}{l}\text { Rel. } \\
\text { Int. } \\
{[\%]}\end{array}$ \\
\hline a. 45.0435 & 8857.41 & 0.2401 & 2.01104 & 100 \\
65.1878 & 1147.96 & 0.3601 & 1.42997 & 12.96 \\
b. 21.9281 & 298.35 & 0.3601 & 4.05008 & 2.11 \\
33.7206 & 227.32 & 0.9604 & 2.65584 & 1.61 \\
45.0542 & $14,161.92$ & 0.2401 & 2.01059 & 100 \\
65.2577 & 1154.96 & 0.2401 & 1.42861 & 8.16 \\
c. 33.5928 & 241.3 & 0.7203 & 2.66566 & 1.74 \\
45.0731 & $13,835.59$ & 0.1801 & 2.00979 & 100 \\
65.3034 & 885.21 & 0.3001 & 1.42772 & 6.4 \\
d. 45.0428 & $13,305.49$ & 0.2401 & 2.01108 & 100 \\
65.2548 & 985.28 & 0.2401 & 1.42867 & 7.41 \\
\hline
\end{tabular}

of the material: whether a polished, corroded, or inhibited material's surfaces. The associated EDS of the as-received spectrum of the abraded sample in Fig. 12a highlights the elements constituting carbon steel sample ( $\mathrm{Fe}, \mathrm{Mn}$, and $\mathrm{C})$ with a high atomic content of iron to $88.63 \%$ (Table 11), in addition to oxygen low signal to $1.80 \%$ related to the airformed oxide film [107]. The attached EDS spectrum of Fig. 12b displays a signal for $\mathrm{Cl}$ to $0.61 \%$ special for the constituent of acid solution, as well as the presence of the 
Table 10 Identified patterns list of the phases obtained from the XRD Patterns of the steel: a-without $\mathrm{HCl}$; b-without inhibitor; c-presence of inhibitor without gallic acid; d-presence of inhibitor with gallic acid

\begin{tabular}{llllll}
\hline Ref. code & Score & Compound name & $\begin{array}{l}\text { Displacement } \\
{\left[{ }^{\circ} \text { 2Th.] }\right.}\end{array}$ & Scale factor & Chemical formula \\
\hline $96-900-6598$ & 99 & Iron & 0 & 0.599 & $\mathrm{Fe}_{2.00}$ \\
$96-900-8570$ & 1 & Graphite & 0 & 0.461 & $\mathrm{C}_{4.00}$ \\
$96-900-0662$ & 66 & Iron & 0 & 1 & $\mathrm{Fe}_{2.00}$ \\
$96-900-3081$ & 5 & Iron oxide & 0 & 0.018 & $\mathrm{Fe}_{4.00} \mathrm{O}_{8.00}$ \\
$96-900-2332$ & 2 & Magnetite & 0 & 0.339 & $\mathrm{Fe}_{24.00} \mathrm{O}_{32.00}$ \\
$96-900-0660$ & 81 & Iron & 0 & 0.406 & $\mathrm{Fe}_{2.00}$ \\
$96-901-4236$ & 6 & Iron oxide & 0 & 0.318 & $\mathrm{Fe}_{4.00} \mathrm{O}_{5.00}$ \\
$96-900-0662$ & 70 & Iron & 0 & 0.987 & $\mathrm{Fe}_{2.00}$ \\
$96-152-4200$ & 18 & Nickel iron & 0 & 0.027 & $\mathrm{Ni}_{0.58} \mathrm{Fe}_{1.42}$ \\
$96-151-4234$ & 8 & Manganese oxide & 0 & 0.097 & $\mathrm{Mn}_{16.27} \mathrm{O}_{32.00}$ \\
$96-151-4107$ & 1 & Bixbyite & 0 & 10.068 & $\mathrm{Mn}_{32.00} \mathrm{O}_{48.00}$ \\
\hline
\end{tabular}

oxygen peak with a higher atomic percentage in this case, which indicates the formation of non-protective corrosion products [108] on the corroded surface. These features may be explained by a serious attack of steel immersed in $1 \mathrm{M}$ $\mathrm{HCl}$ solution. The addition of inhibitor decreases the atomic content of oxygen which indicates a reduction in corrosion attack. This decrease is more apparent with the addition of gallic acid, and also intensity of $\mathrm{Cl}$ peak disappeared at the same time which is consistent with previous findings indicating that this additive is more efficient in increasing corrosion resistance. Therefore, it could be concluded that the covered surface increases and the dissolution of carbon steel decreases. These results suggest the formation of inhibitive and protective film on the steel surface that subdued and overpowered the charge and mass exchange by acting as a blockade and, consequently made the inhibited surface display enhanced properties [109].

\section{Conclusion}

This work was devoted to the examination of the corrosion protection of $\mathrm{C} 38$ in $1 \mathrm{M} \mathrm{HCl}$ acid medium by using of extracts (aqueous and methanolic) of the pulp of $C$. sili$q u a$, without and with addition of gallic acid. The inhibitory properties of these extracts were studied by gravimetric and electrochemical methods (spectroscopy of electrochemical impedance and polarization curves). The following findings were reached of this study:

1. A maximum efficiency is obtained for the aqueous extract of $C$. siliqua with gallic acid at a concentration of $3 \mathrm{~g} / \mathrm{l}$ and the efficiency was $91.32 \%$ at $323 \mathrm{~K}$.

2. The influence of temperature on the kinetics of corrosion has helped understand the mode of action of $C$. siliqua inhibitor.

3. The polarization curves showed a decrease in current density versus concentration.

4. The impedance diagrams showed that this is a process of load transfer on a heterogeneous surface for all the concentrations studied.

5. Based on the polarization results, the studied inhibitor operate as inhibitor of mixed type but the effect on cathodic reactions is greater.

6. The adsorption model obeys Langmuir's isotherm of adsorption.

7. The FTIR spectra analysis confirms the adsorption of $C$. siliqua extracts molecules on the carbon steel surface.

8. EDX, SEM, and XRD confirm the corrosion of carbon steel in $1 \mathrm{M} \mathrm{HCl}$ and its inhibition by $C$. siliqua aqueous extract with gallic acid.

9. The main constituent responsible for corrosion inhibition characteristic of $C$. siliqua extract is found to be gallic acid. 
Fig. 12 SEM and EDS images micrographs for the surface of steel specimens: a after polishing; b without extract; $\mathbf{c}$ with extract in absence of gallic acid; d with extract in the presence of gallic acid

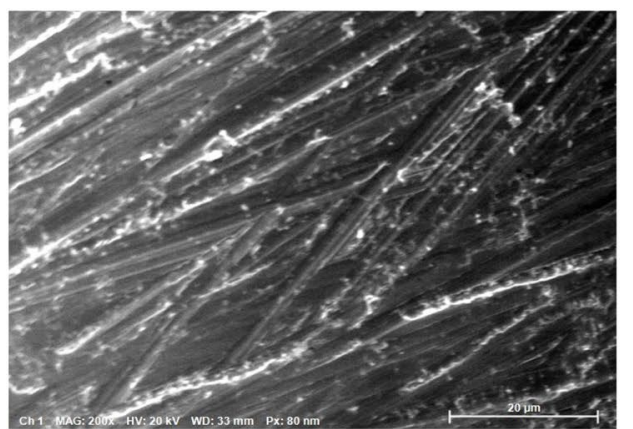

(a)
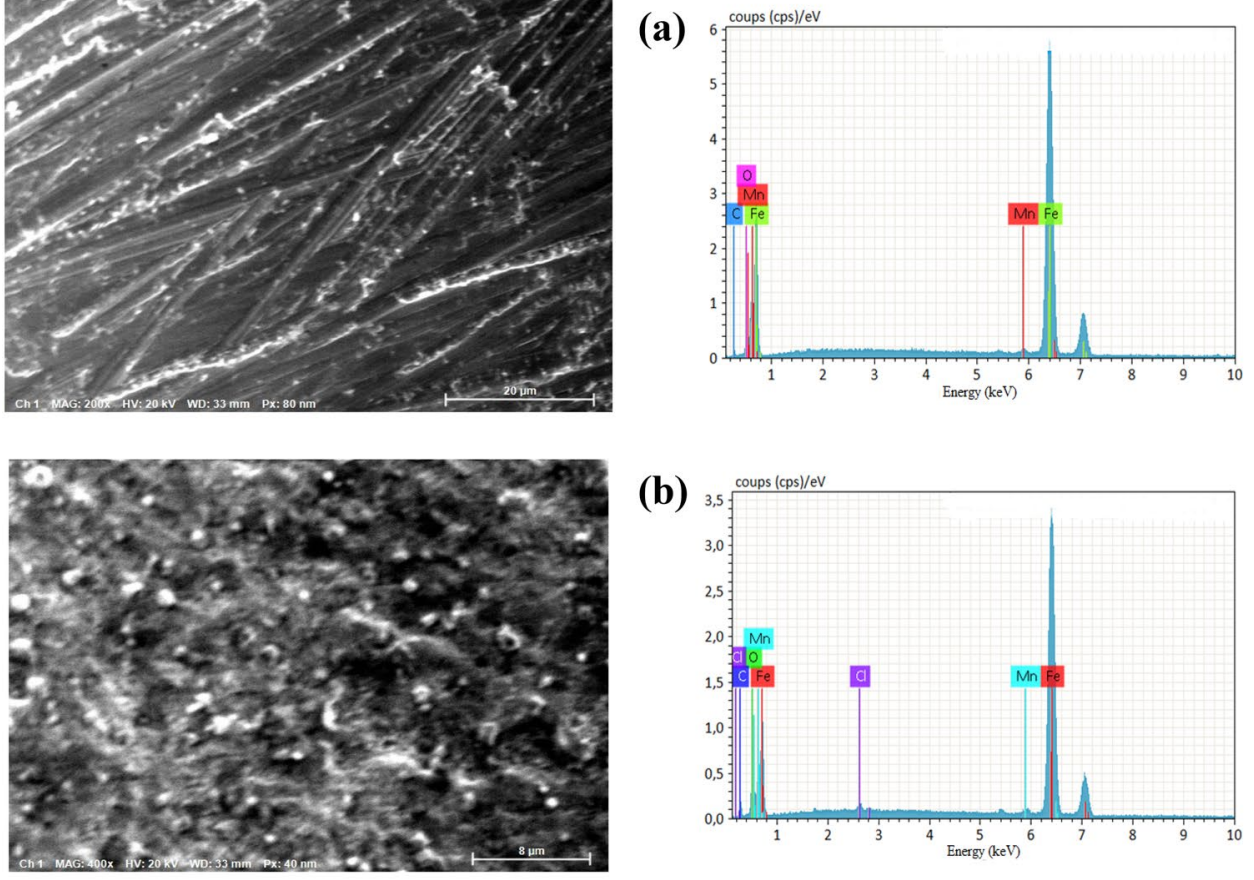

(b)

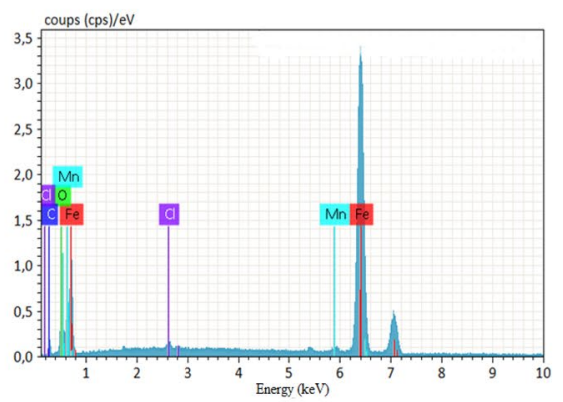

(c)

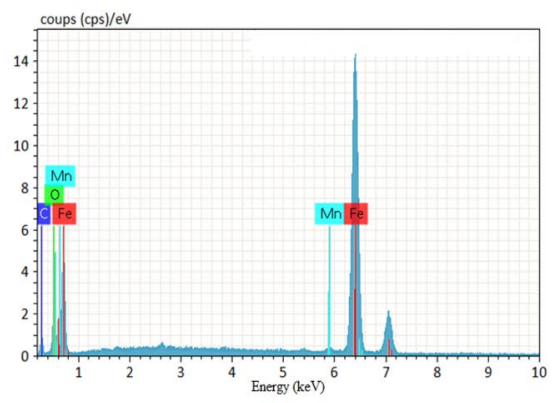

(d)

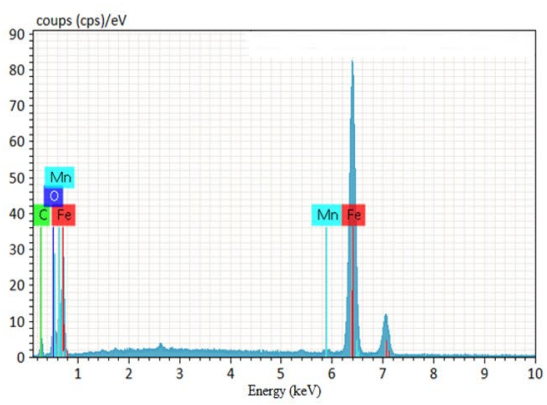


Table 11 Percentage of atomic contents of elements obtained from EDX spectra

\begin{tabular}{llrlrl}
\hline System & \multicolumn{5}{l}{ Percentage of elements detected (\%) } \\
\cline { 2 - 6 } & $\mathrm{Fe}$ & \multicolumn{1}{c}{$\mathrm{C}$} & $\mathrm{Mn}$ & \multicolumn{1}{c}{$\mathrm{O}$} & $\mathrm{Cl}$ \\
\hline After polishing & 88.63 & 8.99 & 0.58 & 1.80 & - \\
Without extract & 58.53 & 18.88 & 0.64 & 21.34 & 0.61 \\
$\begin{array}{l}\text { With extract in the } \\
\text { absence of gallic }\end{array}$ & 58.66 & 23.06 & 0.55 & 17.73 & - \\
$\begin{array}{l}\text { acid } \\
\begin{array}{l}\text { With extract in } \\
\text { presence of gallic }\end{array}\end{array}$ & 58.07 & 23.94 & 0.57 & 17.42 & - \\
acid & & & & & \\
\hline
\end{tabular}

Acknowledgements The authors gratefully acknowledge the CUR CA2D of Chouaib Doukkali University (El Jadida-Morocco) for its support.

Funding There were no research Grants for this work from any funding agencies.

Data Availability All data generated or analyzed during this study are included in this published article (and its supplementary information files).

\section{Declarations}

Conflict of interest The authors declare there is no conflict of interest regarding the publication of this article.

\section{References}

1. EL Bakri, EL Aoufir Y, Bourazmi H, Harmaoui A, Sebhaoui J, Ben Ali A, Oudda H, Guenbour A, Tabyaoui M, Ramli Y, Essassi EM Y (2017) The roles of 3,4-diamino-5-phenyl-4 H-1,2,4-triazole (TR) on the corrosion inhibition of steel in $\mathrm{HCl}$ media. $\mathbf{J}$ Mater Environ Sci 8:33-43

2. Abdallah M, El-Dafrawy AM, Sobhi M, Elwahy AHM, Shaaban MR (2014) Corrosion Inhibition of carbon steel in sulphuric acid solutions by novel bisaminothiazole derivatives: chemical, electrochemical and DFT studies. Int J Electrochem Sci 8:2186-2207

3. Sobhia M, Abdallah M, Hafez E (2013) Some poly sorbate compounds as corrosion inhibitors for carbon steel in hydrochloric acid. J Adv Chem 5:830-838. https://doi.org/10.24297/jac.v5i3. 2679

4. Abdallah M, Asghar BH, Zaafarany I, Sobhi M (2013) Synthesis of some aromatic nitro compounds and its applications as inhibitors for corrosion of carbon steel in hydrochloric acid solution. Protect Metals Phys Chem Surf 49:485-491. https://doi.org/10. 1134/S2070205113040187

5. Fouda AS, Abdallah M, Medhat M (2012) Some Schiff base compounds as inhibitors for corrosion of carbon steel in acidic media. Protect Metals Phys Chem Surf 48:477-486. https://doi. org/10.1134/S2070205112040053

6. Issaadi S, Douadi T, Zaouaoui A, Chafaa S, Khan MA, Bouet G (2011) Novel thiophene symmetrical schiff base compounds as corrosion inhibitor for mild steel in acidic media. Corros Sci 53:1484-1488. https://doi.org/10.1016/j.corsci.2011.01.022
7. Abdallah M, Zaafarany I, Khairou KS, Sobhi M (2012) Inhibition of carbon steel corrosion by iron (III) and imidazole in sulfuric acid. Int J Electrochem Sci 7:1564-1579

8. Zaafarany IA (2014) Corrosion inhibition of 1018 carbon steel in hydrochloric acid using Schiff base compounds. Int J Corros Scale Inhibit 3:012-027. https://doi.org/10.17675/ 2305-6894-2014-3-1-012-027

9. Moretti G, Guidi F, Fabris F (2013) Corrosion inhibition of the mild steel in $0.5 \mathrm{M} \mathrm{HCl}$ by 2-butyl-hexahydropyrrolo [1,2-b] [1,2] oxazole. Corros Sci 76:206-218. https://doi.org/10. 1016/j.corsci.2013.06.044

10. Fouda AS, Abdallah M, Attia A (2010) Inhibition of carbon steel corrosion by some cyanoacetohydrazide derivatives in $\mathrm{HCl}$ solution. Chem Eng Commun 197:1091-1108. https://doi. org/10.1080/0098644903412944

11. Belghiti ME, Tighadouini S, Karzazi Y, Dafali A, Hammouti B, Radi S, Solmaz R (2016) New hydrazine derivatives as corrosion inhibitors for mild steel protection in phosphoric acid medium. Part A: experimental study. J Mater Environ Sci $7: 337-346$

12. Verma CB, Quraishi MA, Singh A (2015) 2-Aminobenzene1,3-dicarbonitriles as green corrosion inhibitor for mild steel in $1 \mathrm{M} \mathrm{HCl}$ : electrochemical, thermodynamic, surface and quantum chemical investigation. J Taiwan Inst Chem Eng 49:229-239. https://doi.org/10.1016/j.jtice.2014.11.029

13. Boumhara K, Tabyaoui M, Jama C, Bentiss F (2015) Artemisia Mesatlantica essential oil as green inhibitor for carbon steel corrosion in $1 \mathrm{M} \mathrm{HCl}$ solution: electrochemical and XPS investigations. J Ind Eng Chem 29:146-155. https://doi.org/10. 1016/j.jiec.2015.03.028

14. Kabel KI, Zakaria K, Abbas MA, Khamis EA (2015) Assessment of corrosion inhibitive behavior of 2-aminothiophenol derivatives on carbon steel in 1M HCl. J Ind Eng Chem 23:5766. https://doi.org/10.1016/J.JIEC.2014.07.042

15. Al-Luaibi SS, Azad S, Taobi AH (2011) Thermodynamic properties of amino melamine formaldehyde as corrosion inhibitor for steel in sulfuric acid solution. J Mater Environ Sci 2:148-155

16. Ramananda MS (2013) A green approach: a corrosion inhibition of mild steel by adhatoda vasica plant extract in $0.5 \mathrm{M}$ $\mathrm{H}_{2} \mathrm{SO}_{4}$. J Mater Environ Sci 4:119-126

17. Ostovari A, Hoseinieh SM, Peikari M, Shadizadeh SR, Hashemi SJ (2009) Corrosion inhibition of mild steel in $1 \mathrm{M} \mathrm{HCl}$ solution by henna extract: a comparative study of the inhibition by henna and its constituents (lawsone, Gallic acid, a-D-Glucose and tannic acid). Corros Sci 51:1935-1949. https://doi.org/10.1016/j.corsci.2009.05.024

18. Lebe N, George N, Justus N, Nneka E, Peter E (2016) Aqueous extracts of Pentaclethra macrophylla bentham roots as eco-friendly corrosion inhibition for mild steel in $0.5 \mathrm{M} \mathrm{KOH}$ medium. Int J Mater Chem 6:12-18. https://doi.org/10.5923/j. ijmc. 20160601.03

19. Ali D, Ghasem B, Bahram R, Mohammad R (2019) Potential of Borage flower aqueous extract as an environmentally sustainable corrosion inhibitor for acid corrosion of mild steel: electrochemical and theoretical studies. J Mol Liq 277:895-911. https://doi. org/10.1016/j.molliq.2019.01.008

20. Sharma KS, Ackmez M, Gargi J, Jyoti S (2010) Corrosion inhibition and adsorption properties of Azadirachta indica mature leaves extract as green inhibitor for mild steel in $\mathrm{HNO}_{3}$. Green Chem Lett Rev 3:7-15. https://doi.org/10.1080/1751825090 3447100

21. Murthy ZVP, Vijayaragavan K (2014) Mild steel corrosion inhibition by acid extract of leaves of Hibiscus sabdariffa as a green corrosion inhibitor and sorption behavior. Green Chem Lett Rev 7:209-219. https://doi.org/10.1080/17518253.2014.924592 
22. Haldhar R, Prasad D, Mandal N, Benhiba F, Bahadur I, Dagdag O (2021) Anticorrosive properties of a green and sustainable inhibitor from leaves extract of Cannabis sativa plant: experimental and theoretical approach. Colloids Surf A 614:126211. https://doi.org/10.1016/j.colsurfa.2021.126211

23. Janaina CR, José ACPG, Eliane D (2014) Aqueous extracts of mango and orange peel as green inhibitors for carbon steel in hydrochloric acid solution. Mater Res 17:1581-1587. https://doi. org/10.1590/1516-1439.285014

24. Rajesh H, Dwarika P, Indra B, Omar D, Avni B (2021) Evaluation of Gloriosa superba seeds extract as corrosion inhibition for low carbon steel in sulfuric acidic medium: a combined experimental and computational studies. J Mol Liq 323:114958. https:// doi.org/10.1016/j.molliq.2020.114958

25. Sangeetha M, Rajendran S, Sathiyabama J, Umasankareswari T, Krishnaveni A, Joany RM (2015) Corrosion inhibition by flower extracts: an overview. Int J Nano Corr Sci Eng 2:14-21

26. Prabha AS, Kavitha KG, Shrine B, Rajendran S (2020) Inhibition of corrosion of mild steel in simulated oil well water by an aqueous extract of Andrographis paniculata. Indian J Chem Technol 27:452-460

27. El Hamdani N, Fdil R, Tourabi M, Jama C, Bentiss F (2015) Alkaloids extract of Retama monosperma (L.) Boiss. Seeds used as novel eco-friendly inhibitor for carbon steel corrosion in $1 \mathrm{M}$ $\mathrm{HCl}$ solution: electrochemical and surface studies. Appl Surf Sci 357:1294-1305. https://doi.org/10.1016/j.apsusc.2015.09.159

28. Kathiravan S, Jyothi S, Ayyannan G, Ravichandran J, Raja G (2021) Inhibitory action of aqueous Ruellia tuberosa L. leaves extract on the corrosion of copper in $\mathrm{HCl}$ solution. J Indian Chem Soc 98:100207. https://doi.org/10.1016/j.jics.2021.100207

29. Benmansour N, Cherif H, El Hanballi F, Akssira M (2020) Study of the biological activities of the seeds of the plant Ceratonia sili$q u a \mathrm{~L}$. recovered in the Bejaia region. Med Technol J 4:520-521. https://doi.org/10.26415/2572-004X-vol4iss1p520-521

30. Santos LM, Tulio LT, Campos LF, Dorneles MR, Krüger CCH (2015) Glycemic response to Carob (Ceratonia siliqua L.) in healthy subjects and with the in vitro hydrolysis index. Nutr Hosp 31:482-487. https://doi.org/10.3305/nh.2015.31.1.8011

31. Zhu B, Zayed MZ, Zhu H, Zhao J, Shao-Ping L (2019) Functional polysaccharides of carob fruit: a review. Chin Med 14:40

32. Salih G, Jilal A (2020) Utilisation alimentaire de la pulpe de caroube: formulation et test consommateur. Rev Mar Sci Agron Vét 8:249-252

33. Avallone R, Plessi M, Baraldi M, Monzani A (1997) Determination of chemical composition of carob (Ceratonia siliqua): protein, fat, carbohydrates, and tannins. J Food Compos Anal 10:166-172. https://doi.org/10.1006/jfca.1997.0528

34. Marakis S (1996) Carob bean in food and feed: current status and future potentials-a critical appraisal. J Food Sci Technol 33:365-383

35. Loeb H, Vandenplas Y, Würsch P, Guesry P (1989) Tannin-rich carob pod for the treatment of acute onset diarrhea. J Pediatr Gastroenterol Nutr 8:480-485

36. Batlle I, Tous J (1997) Promoting the conservation and use of underutilized and neglected crops (carob tree, Ceratonia siliqua L.). International Plant Genetic Resources Institute (IPGRI), Rome

37. Ait Chitt M, Belmir M, Lazrak A (2007) Production des plantes sélectionnées et greffées du caroubier. Transfert de technologie en Agriculture 153:1-4

38. Sbay H, Abourouh M (2006) Apport des espèces à usages multiples pour le développement durable: cas du pin pignon et du caroubier, Centre de Recherche Forestière Haut-Commissariat aux Eaux et Forêts et à la Lutte Contre la Désertification, Rabat $1-9$
39. Serairi-Beji R, Mekki-Zouiten L, Tekaya-Manoubi L, Loueslati MH, Guemira F, Ben Mansour A (2000) Can carob powder be used with oral rehydration solution for the treatment of acute diarrhea. Med Trop 60:125-128

40. Rejeb MN (1995) Le caroubier en Tunisie: Situations et perspectives d'amélioration. Quel avenir pour l'amélioration des plantes? Edit. AUPELF-UREF. John Libbey Eurotext, Paris, pp 79-85

41. Berrougui H (2007) Le caroubier (Ceratonia siliqua L.), une richesse nationale aux vertus médicinales. Maghreb Canada Express 5

42. Ruiz-Roso B, Quintela JC, Fuente EDL, Haya J, Pérez-Olleros L (2010) Insoluble carob fiber rich in polyphenols lowers total and LDL cholesterol in hypercholesterolemic sujects. Plant Foods Hum Nutr 65:50-60. https://doi.org/10.1007/s11130-009-0153-9

43. Nasar-Abbas SM, Huma Z, Thi-Huong V, Khan MK, Esbenshade H, Jayasena V (2016) Carob kibble: a bioactive-rich food ingredient. Compr Rev Food Sci Food Saf 15:63-72. https://doi.org/10. 1111/1541-4337.12177

44. Marakis S, Marakis G, Lambraki M (1997) Tannins of eight carob varieties from the Island of Lefkada, Greece. Chim Chron New Series 26:57-66

45. Dhahir BM, Hameed IH, Jaber AR (2017) Prospective and retrospective study of fractures according to trauma mechanism and type of bone fracture. Res J Pharm Tech 10:1994-2002. https:// doi.org/10.5958/0974-360X.2017.00692.8

46. Eldahshan OA (2011) Isolation and structure elucidation of phenolic compounds of carob leaves grown in Egypt. Curr Res J Biol Sci 3:52-55

47. Sakakibara H, Honda Y, Nakagawa S, Ashida H, Kanazawa K (2003) Simultaneous determination of all polyphenols in vegetables, fruits, and teas. J Agric Food Chem 51:571-581. https://doi. org/10.1021/jf0209261

48. Samanidou V, Tsagiannidis A, Sarakatsianos I (2012) Simultaneous determination of polyphenols and major purine alkaloïds in Greek Sideritis species, herbal extracts, green tea, black tea, and coffee by high-performance liquid chromatography-diode array detection. J Sep Sci 35:608-615. https://doi.org/10.1002/ jssc. 201100894

49. Schmitzer V, Slatnar A, Veberic R, Stampar F, Solar A (2011) Roasting affects phenolic composition and antioxidative activity of hazelnuts (Corylus avellana L.). J Food Sci 76:14-19. https:// doi.org/10.1111/j.1750-3841.2010.01898.x

50. Shahrzad S, Aoyagi K, Winter A, Koyama A, Bitsch I (2001) Pharmacokinetics of gallic acid and its relative bioavailability from tea in healthy humans. J Nutr 131:1207-1210. https://doi. org/10.1093/jn/131.4.1207

51. Damiani E, Bacchetti T, Padella L, Tiano L, Carloni P (2014) Antioxidant activity of different white teas: comparison of hot and cold tea infusions. J Food Compos Anal 33:59-66. https:// doi.org/10.1016/j.jfca.2013.09.010

52. Qu W, Breksa AP III, Pan Z, Ma H (2012) Quantitative determination of major polyphenol constituents in pomegranate products. Food Chem 132:1585-1591. https://doi.org/10.1016/j.foodc hem.2011.11.106

53. Tako E, Beebe SE, Reed S, Hart JJ, Glahn RP (2014) Polyphenolic compounds appear to limit the nutritional benefit of biofortified higher iron black bean (Phaseolus vulgaris L.). J. Nutr 13:28. https://doi.org/10.1186/1475-2891-13-28

54. Li J, He X, Li M, Zhao W, Liu L, Kong X (2015) Chemical fingerprint and quantitative analysis for quality control of polyphenols extracted from pomegranate peel by HPLC. Food Chem 176:7-11. https://doi.org/10.1016/j.foodchem.2014.12.040

55. Nowak R, Olech M, Nowacka N (2014) Chapter 97-plant polyphenols as chemopreventive agents. Polyphen Human Health 
Dis 2:1289-1307. https://doi.org/10.1016/B978-0-12-3984562.00086-4

56. Haddock EA, Gupta RK, Al-Shafi SMK, Layden K, Haslam E, Magnolato D (1982) The metabolism of gallic acid and hexahydroxydiphenic acid in plants: biogenetic and molecular taxonomic considerations. Phytochemistry 21:1049-1062. https://doi. org/10.1016/S0031-9422(00)82415-2

57. Kumbhar AG, Kishore K, Venkateswaran G, Balaji V (2003) Dissolution of nickel ferrite and rare earths containing magnetite in citric acid-EDTA-gallic acid formulation. Hydrometallurgy 68:171-181. https://doi.org/10.1016/S0304-386X(02)00202-5

58. Boumagoura M, Ghizellaoui S, Rhouati S, Cheap-Charpentier $\mathrm{H}$, Horner O (2021) Calcium carbonate scaling prevention by a green chemical inhibitor, gallic acid. Water Environ J 35:9981006. https://doi.org/10.1111/wej.12690

59. Saeed S, Aslam S, Mehmood T, Naseer R, Nawaz S, Mujahid H, Firyal S, Anjum AA, Sultan A (2021) Production of gallic acid under solid-state fermentation by utilizing waste from food processing industries. Waste Biomass Valor 12:155-163. https:// doi.org/10.1007/s12649-020-00980-z

60. Nishimura T, Wang LY, Kusano K, Kitanaka S (2005) Flavonoids that mimic human ligands from the whole plants of Euphorbia lunulata. Chem Pharm Bull 53:305-308. https://doi.org/10.1248/ cpb.53.305

61. Hale AL (2003) Screening potato genotypes for antioxidant activity, identification of the responsible compounds, and differentiating Russet Norkotah strains using AFLP and microsatellite marker analysis. Office of Graduate studies of Texas A\&M University. Genetics, 260

62. You BR, Park WH (2010) Gallic acid-induced lung cancer cell death is related to glutathione depletion as well as reactive oxygen species increase. Toxicol In Vitro 24:1356-1362. https://doi. org/10.1016/j.tiv.2010.04.009

63. Kratz JM, Andrighetti-Fröhner CR, Leal PC, Nunes RJ, Yunes RA, Trybala E, Bergström T, Barardi CRM, Simões CMO (2008) Evaluation of anti-HSV-2 activity of gallic acid and pentyl gallate. Biol Pharm Bull 31:903-907. https://doi.org/10.1248/bpb. 31.903

64. Umar HI, Siraj B, Ajayi A, Jimoh T, Chukwuemeka PO (2021) Molecular docking studies of some selected gallic acid derivatives against five non-structural proteins of novel coronavirus. J Genet Eng Biotechnol 19:16. https://doi.org/10.1186/ s43141-021-00120-7

65. Erlund I (2004) Review of the flavonoids quercetin, hesperetin, and naringenin. Dietary sources, bioactivities, bioavailability, and epidemiology. Nutr Res 24:851-874. https://doi.org/10. 1016/j.nutres.2004.07.005

66. Murray AP, Rodriguez S, Frontera MA, Tomas MA, Mulet MC (2004) Antioxidant metabolites from Limonium brasiliense (Boiss.) Kuntze. Z Naturforsch 59:477-480. https://doi.org/10. 1515/znc-2004-7-804

67. Keny SJ, Kumbhar AG, Thinaharan C, Venkateswaran G (2008) Gallic acid as a corrosion inhibitor of carbon steel in chemical decontamination formulation. Corros Sci 50:411-419. https:// doi.org/10.1016/j.corsci.2007.06.024

68. Favre M, LANDOLT D, (1993) The influence of Gallic acid on the reduction of rust on painted steel surfaces. Corros Sci 34:1481-1494. https://doi.org/10.1016/0010-938X(93)90243-A

69. Ohtani Y, Horiuchi A, Yamaguchi A, Oyaizu K, Yuasa M (2006) Non cyanide electroless gold plating using polyphenols as reducing agents. J Electrochem Soc 153:63-66. https://doi.org/10. $1149 / 1.2133716$

70. Obot IB, Madhankumar A (2015) Enhanced corrosion inhibition effect of tannic acid in the presence of gallic acid at mild steel/ $\mathrm{HCl}$ acid solution interface. J Ind Eng Chem 25:105-111. https:// doi.org/10.1016/j.jiec.2014.10.019
71. Azab A (2017) Carob (Ceratonia siliqua): health, medicine and chemistry. Eur Chem Bull 610:456-469. https://doi.org/10. 17628/ecb.2017.6.456-469

72. Puigventos L, Navarro M, Alechaga, E, Núnez O, Saurina J, Hernandez-Cassou S, Puignou L (2015) Determination of polyphenolic profiles by liquid chromatography-electrospray-tandem mass spectrometry for the authentication of fruit extracts. Anal Bioanal Chem 407:597-608. https://doi.org/10.1007/ s00216-014-8298-2

73. Fadel F, Fattouch S, Tahrouch S, Lahmar R, Benddou A, Hatimi A (2011) The phenolic compounds of Ceratonia siliqua pulps and seeds. J Mater Environ Sci 2:285-292

74. Ydjedd S, Chaalal M, Richard G, Kati DE, López-Nicolás R, Fauconnier ML, Louaileche H (2017) Assessment of antioxidant potential of phenolic compounds fractions of Algerian Ceratonia siliqua L. pods during ripening stages. Int Food Res J 24:2041-2049

75. Goulas V, Georgiou E (2020) Utilization of carob fruit as sources of phenolic compounds with antioxidant potential: extraction optimization and application in food models. Foods 9:20. https:// doi.org/10.3390/foods 9010020

76. Akalezi CO, Enenebaku CK, Oguzie EE (2013) Inhibition of acid corrosion of mild steel by biomass extract from the petersianthus macrocarpus plant. J Mater Environ Sci 4:217-226

77. El-Hajjaji F, Belkhmima RA, Zerga B, Sfaira M, Taleb M, Ebn Touhami M, Hammouti B (2014) Time and temperature elucidation on steel corrosion inhibition by 3-methyl-1-prop-2-ynylquinoxalin-2 $(1 \mathrm{H})$-one in molar hydrochloric acid: part 2. J Mater Environ Sci 5:263-270

78. Fouda AS, Shalabi K, Idress AA (2015) Ceratonia siliqua extract as a green corrosion inhibitor for copper and brass in nitric acid solutions. Green Chem Lett Rev 8:17-29. https://doi.org/10. 1080/17518253.2015.1073797

79. Chefira K, Nmila R, Benabbouha T, Siniti M, Rchid H, El Attari $\mathrm{H}$ (2021) Origanum Elongatum as a green corrosion inhibitor for C38 steel in an acidic medium. J Fail Anal and Preven 21:16831696. https://doi.org/10.1007/s11668-021-01218-3

80. Ali EH, Himdan TA, Ahmed ZW (2019) Gallic acid as corrosion inhibitor for aluminum 6061 in alkali solutions. Ibn Al-Haitham J Pure Appl Sci 32:17-27. https://doi.org/10.30526/32.1.1983

81. Bammou L, Belkhaouda M, Salghi R, Benali O, Zarrouk A, Zarrok H, Hammouti B (2014) Corrosion inhibition of steel in sulfuric acidic solution by the Chenopodium Ambrosioides extracts. J Assoc Arab Univ Basic Appl Sci 16:83-90. https:// doi.org/10.1016/j.jaubas.2013.11.001

82. Hussin MH, Kassim MJ, Razali NN, Dahon NH, Nasshorudin D (2016) The effect of Tinospora crispa extracts as a natural mild steel corrosion inhibitor in $1 \mathrm{M} \mathrm{HCl}$ solution. Arab J Chem 9:616-624. https://doi.org/10.1016/j.arabjc.2011.07.002

83. Boudalia M, Fernández-Domene RM, Tabyaoui MH, Bellaouchou A, Guenbour A, García-Antón J (2019) Green approach to corrosion inhibition of stainless steel in phosphoric acid of Artemesia herba albamedium using plant extract. J Market Res 8:5763-5773. https://doi.org/10.1016/j.jmrt.2019.09.045

84. Mirinioui A, El Attari H, Fdil R, Zefzoufi M, Jorio S (2021) Dysphania ambrosioides essential oil: an eco-friendly inhibitor for mild steel corrosion in hydrochloric and sulfuric acid medium. J Bio Tribo Corros 7:150. https://doi.org/10.1007/ s40735-021-00584-7

85. Chebli H, Batah A, Asdadi A, Zaafrani M, IdrissiHassani LM, Bounimi S, Chebli B, Salghi R (2017) Corrosion inhibition of steel in 1M hydrochloric acid medium by Thymus leptobotrys essential oils. Appl J Environ Eng Sci 3:131-143. https://doi. org/10.48422/IMIST.PRSM/ajees-v3i2.8997

86. Batah A, Anejjar A, Belkhaouda M, Bammou L, Bazzi L, Hammouti B (2016) Effect of nitrophenyl derivatives on the carbon 
steel corrosion behavior in acidic medium: experimental and theoretical studies. Appl J Environ Sci 2:56-71. https://doi.org/ 10.48422/IMIST.PRSM/ajees-v2i2.7102

87. Benabbouha T, Nmila R, Siniti M, Chefira K, El Attari H, Rchid H (2020) The brown algae Cystoseira Baccata extract as a friendly corrosion inhibitor on carbon steel in acidic media. SN Appl Sci 2:662. https://doi.org/10.1007/s42452-020-2492-y

88. Ghazi I, Jorio S, Siniti M, Fdil R, Elattari H (2021) Experimental and theoretical studies on corrosion inhibitory action of harmala (L) seeds extract on carbon steel in $1 \mathrm{M} \mathrm{HCl}$. Morroccan J Chem 9:542-563. https://doi.org/10.48317/IMIST.PRSM/morjchemv9i3.22928

89. About S, Chellouli M, Zouarhi M, Benzidia B, Hammouch H, Chebabe D, Dermaj A, Erramli H, Bettach N, Hajjaji N (2018) New formulation based on Ceratonia siliqua L. seed oil, as a green corrosion inhibitor of iron in acidic medium. Anal Bioanal Electrochem 10:789-804

90. Lebrini M, Robert F, Roos C (2011) Alkaloids extract from Palicourea guianensis plant as corrosion inhibitor for $\mathrm{C} 38$ steel in $1 \mathrm{M}$ hydrochloric acid medium. Int J Electrochem Sci 6:847-859

91. Morad MS (2008) Inhibition of iron corrosion in acid solutions by Cefatrexyl: behaviour near and at the corrosion potential. Corros Sci 50:436-448. https://doi.org/10.1016/j.corsci.2007.08.018

92. ElAttari H, Lahmadi K, El bribri A, Siniti M (2015) The adsorption and corrosion inhibition of non-ionic surfactant on carbon steel surface in hydrochloric acid. J Mater Chem 5:77-83. https:// doi.org/10.5923/j.ijmc.20150503.04

93. Saeed MM, Ahmed M (2006) Effect of temperature on kinetics and adsorption profile of endothermic chemisorption process: Tm (III)-PAN loaded PUF system. Sep Sci Technol 41:705-722. https://doi.org/10.1080/01496390500527993

94. Martinez S, Stern I (2002) Thermodynamic characterization of metal dissolution and inhibitor adsorption processes in the low carbon steel/mimosa tannin/sulfuric acid system. Appl Surf Sci 199:83-89. https://doi.org/10.1016/S0169-4332(02)00546-9

95. Cang H, Fei Z, Shao J, Shi W, Xu Q (2013) Corrosion inhibition of mild steel by aloes extract in $\mathrm{HCl}$ solution medium. Int $\mathrm{J}$ Electrochem Sci 8:720-734

96. Obot IB, Obi-Egbedi NO, Eseola AO (2011) Anticorrosion potential of 2-mesityl-1H-imidazo [4, 5-f] [1, 10] phenanthroline on mild steel in sulfuric acid solution: experimental and theoretical study. Ind Eng Chem Res 50:2098-2110. https://doi. org/10.1021/ie102034c

97. Bouknana D, Hammouti B, Messali M, Aouniti A, Sbaa M (2014) Olive pomace extract (OPE) as corrosion inhibitor for steel in $\mathrm{HCl}$ medium. Asian Pac J Trop Dis 4:963-974. https:// doi.org/10.1016/S2222-1808(14)60767-2

98. Eddy NO, Ebenso EE, Ibok UJ (2010) Adsorption, synergistic inhibitive effect and quantum chemical studies of ampicillin (AMP) and halides for the corrosion of mild steel in $\mathrm{H}_{2} \mathrm{SO}_{4}$. J Appl Electrochem 40:445-456. https://doi.org/10.1007/ s10800-009-0015-Z
99. Yaqo EA, Anaee RA, Abdulmajeed MH, Tomi IHR, Kadhim MM (2019) Aminotriazole derivative as anti-corrosion material for Iraqi kerosene tanks: electrochemical, computational and the surface study. ChemistrySelect 4:9883-9892. https://doi.org/10. 1002/slct.201902398

100. Emran KM (2015) Effects of concentration and temperature on the corrosion properties of the $\mathrm{Fe}-\mathrm{Ni}-\mathrm{Mn}$ alloy in $\mathrm{HCl}$ solutions. Res Chem Intermed 41:3583-3596. https://doi.org/10.1007/ s11164-013-1473-9

101. Fouda AS, Mohamed OA, Elabbasy HM (2021) Ferula hermonis plant extract as safe corrosion inhibitor for zinc in hydrochloric acid solution. J Bio- Tribo-Corros 7:135. https://doi.org/10.1007/ s40735-021-00570-z

102. Benabbouha T, Siniti M, El Attari H, Chefira K, Chibi F, Nmila R, Rchid H (2018) Red Algae Halopitys incurvus extract as a green corrosion inhibitor of carbon steel in hydrochloric acid. J Bio- Tribo-Corros 4:39. https://doi.org/10.1007/ s40735-018-0161-0

103. Flores-De los Ríos JP, Sánchez-Carrillo M, Nava-Dino CG, Chacón-Nava JG, González-Rodríguez JG, Huape-Padilla E, Neri-Flores MA, Martínez-Villafañe A (2015) Opuntia ficusindica extract as green corrosion inhibitor for carbon steel in $1 \mathrm{M}$ HCl solution. J Spectrosc. https://doi.org/10.1155/2015/714692

104. Hamdy A, El-Gendy N (2013) Thermodynamic, adsorption and electrochemical studies for corrosion inhibition of carbon steel by henna extract in acid medium. Egypt J Pet 22:17-25. https:// doi.org/10.1016/j.ejpe.2012.06.002

105. Flores-De los Ríos JP, Sánchez-Carrillo M, Nava-Dino CG, Chacón-Nava J, Escobedo-Bretado MA, Monreal-Romero HA, Bautista-Margulis RG, Neri-Flores MA, Martínez-Villafañe A (2015) Corrosion inhibition of mild steel using Agavoideae extract in $1 \mathrm{M} \mathrm{HCl}$ solution. Int $\mathrm{J}$ Electrochem Sci 10:10210-10222

106. Okiemute O, Ochuko GU, Basil OO (2021) Corrosion inhibition for alloy 304L (UNS S30403) in H2SO4 1M solution by Centrosema pubescens leaves extract. Appl Surf Sci Adv 3:100061. https://doi.org/10.1016/j.apsadv.2021.100061

107. Deyab MA (2014) Hydrogen generation by tin corrosion in lactic acid solution promoted by sodium perchlorate. J Power Sources 268:765-770. https://doi.org/10.1016/j.jpowsour.2014.06.124

108. Fazal MA, Rubaiee S, Al-Zahrani A (2019) Overview of the interactions between automotive materials and biodiesel obtained from different feedstocks. Fuel Process Technol 196:106178. https://doi.org/10.1016/j.fuproc.2019.106178

109. Chaitra TK, Mohana KN, Tandon HC (2016) Study of new thiazole based pyridine derivatives as potential corrosion inhibitors for mild steel: theoretical and experimental approach. J. Corros, Int. https://doi.org/10.1155/2016/9532809

Publisher's Note Springer Nature remains neutral with regard to jurisdictional claims in published maps and institutional affiliations. 